Historic, Archive Document

Do not assume content reflects current scientific knowledge, policies, or practices. 



\subsection{9}

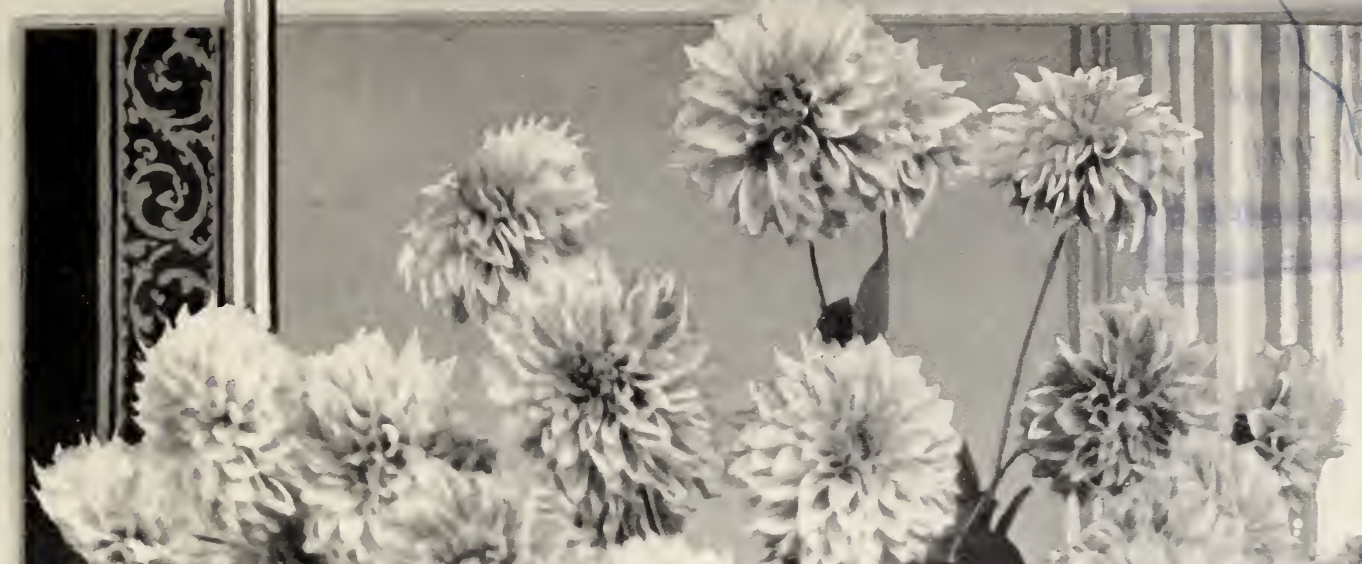

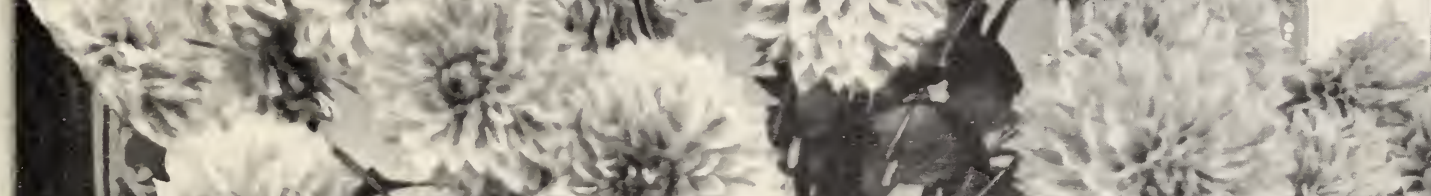

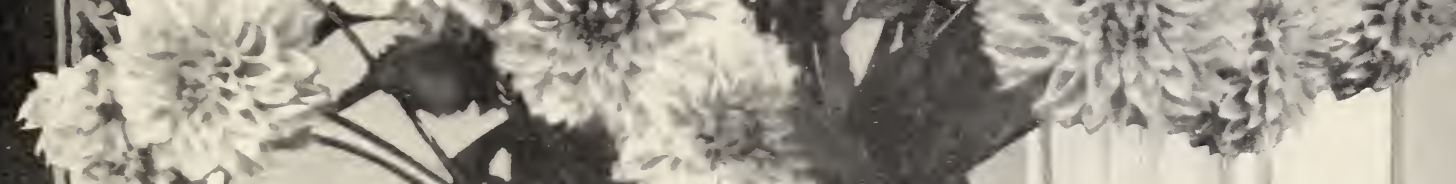

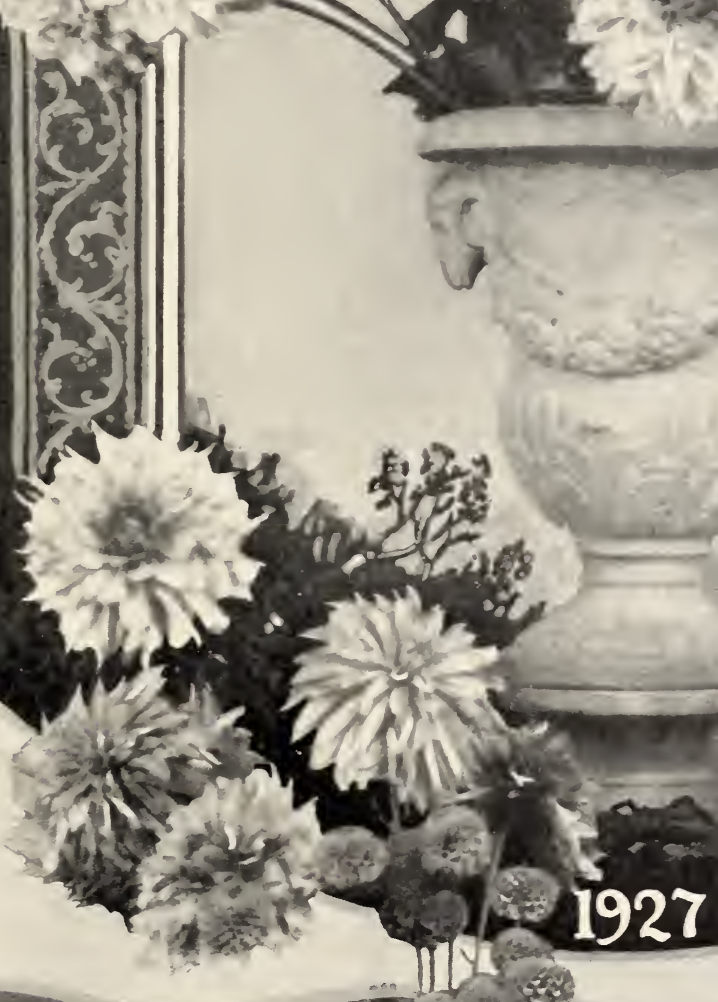

III 2 ze

20,

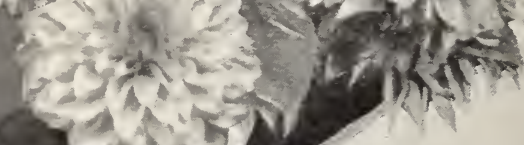

JESSIE L SEAL
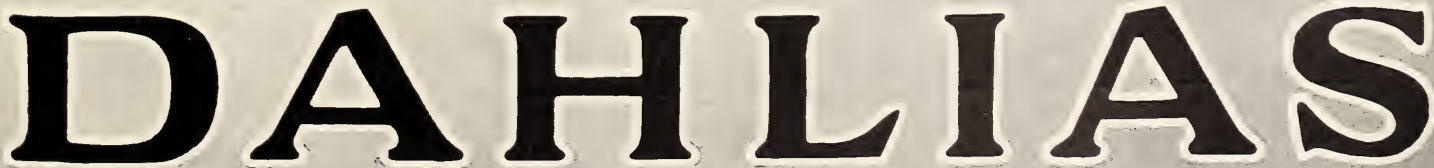


\title{
PRIZES WON
}

\author{
AT THE
}

ELEVENTH ANNUAL EXHIBITION OF THE

DAHLIA SOCIETY OF CALIFORNIA, 1926

\section{æ}

First Prize-Best General Display (Gold Medal).

First Prize-Best Collection of California Dahlias (Cup).

First Prize-Best 50 Blooms, One Variety (Gold Medal).

First Prize-Best Display of New Jersey Dahlias (Gold Medal).

First Prize-Best Basket of Single Dahlias.

First Prize_Best Collection of Pompon Dahlias.

First Prize-Most Artistic Basket of Cactus Dahlias.

First Prize-Best Basket of Autumn Colored Dahlias.

First Prize-Best Gold Colored Dahlia.

First Prize-Best Basket of Peony Dahlias.

First Prize-Best Basket of California Dahlias.

First Prize-Best Basket of Show Dahlias.

Second Prize-Best Twenty-five Blooms, One Variety

Second Prize-Best Basket of Pink Dahlias.

Second Prize-Best Established Three Year Seedling.

Second Prize-Best Collection of Unregistered Seedlings.

Second Prize-Best Basket of California Pompon Dahlias.

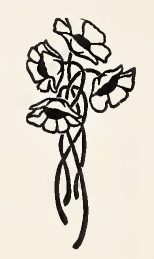

\section{The Dahlia Society of California}

We extend a cordial invitation to all who are interested in dahlias to join the Dahlia Society of California.

The dahlia bulletins that are issued several times a year are full of interesting dahlia news. Yearly dues, $\$ 2.00$.

\section{MEMBER:}

American Dahlia Society California State Floral Society 


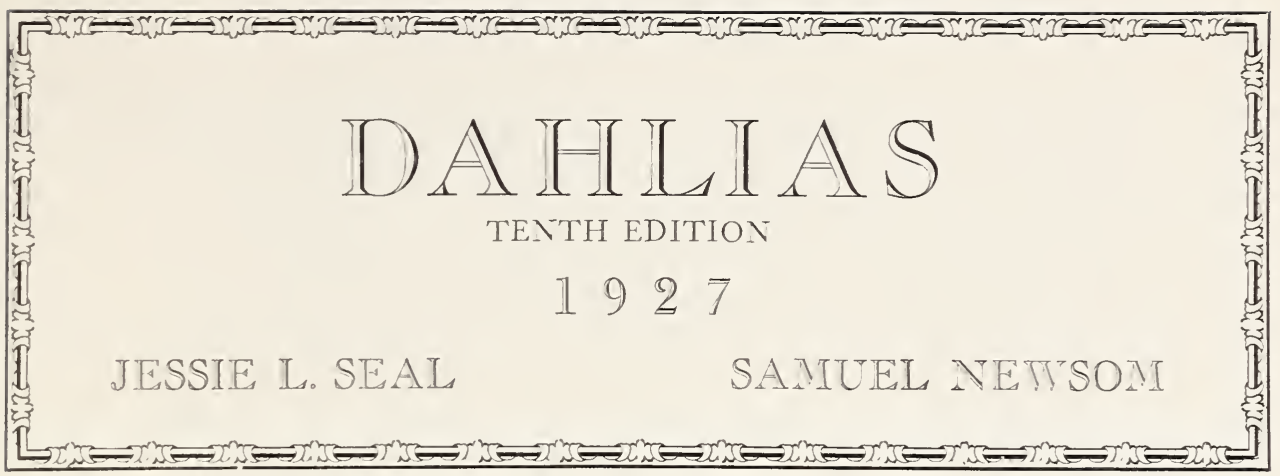

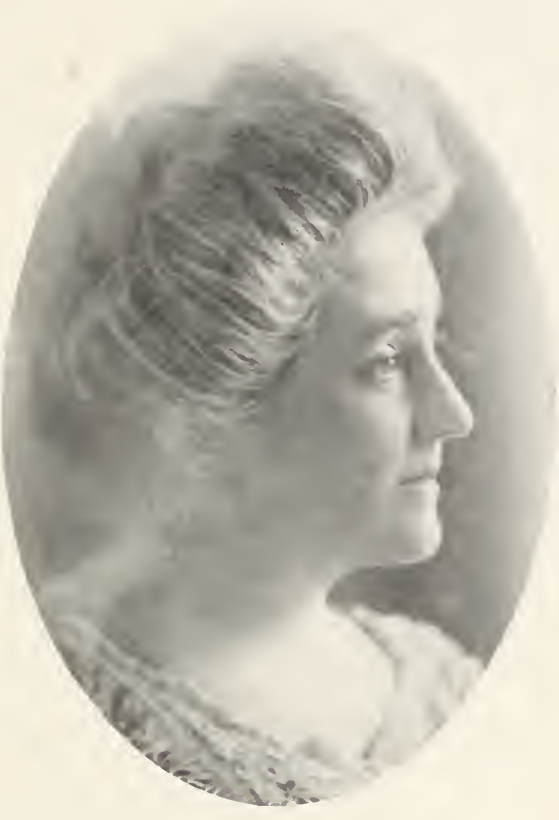

JESSIE L. SEAL

This past Season has been a most enjoyable one, as so many of our dahlia friends were visitors at our Napa gardens. Our only regret is that all of you could not have had this pleasure of seeing our California dahlias at home.

Although the Annual Exhibition of the Dahlia Society of California was much earlier than usual and our flowers were not at their fullest bloom, we were more successful than ever in winning, being awarded a total of twenty Prizes, of which twelve were firsts. These included three Gold Medals (Best General Display, Best Fifty Blooms, and Best Collection of New Jersey Dahlias) and the Palace Hotel Trophy Cup for the Best Col'ection of California Dahlias, making the third consecutive year we have won this most coreted prize.

With continued thanks for your loyalty and the hope that this catalog will be of further interest, we wish you all success and great pleasure with your dahlias for the coming season.

Our office will remain at 607 Third Arenue, where all order's and communications should be addressed.

JESSIE L. SEAL.

607 Third Are.

San Francisco, California.

FLLL DIRECTIONS-For planting, growing and exhibiting dahlias enclosed with each order.

ORDER EARLY-To prevent disappointment

TERMS-Remittance with order. All retail orders sent postage prepaid at your planting time, unless otherwise requested.

WE GUARANTEE-AIl tubers true to name and TO GROW. Orders carefully filled from selected, field grown divided tubers. We do not substitute unless requested. We do not guarantee tubers against freezing if sent before April first.

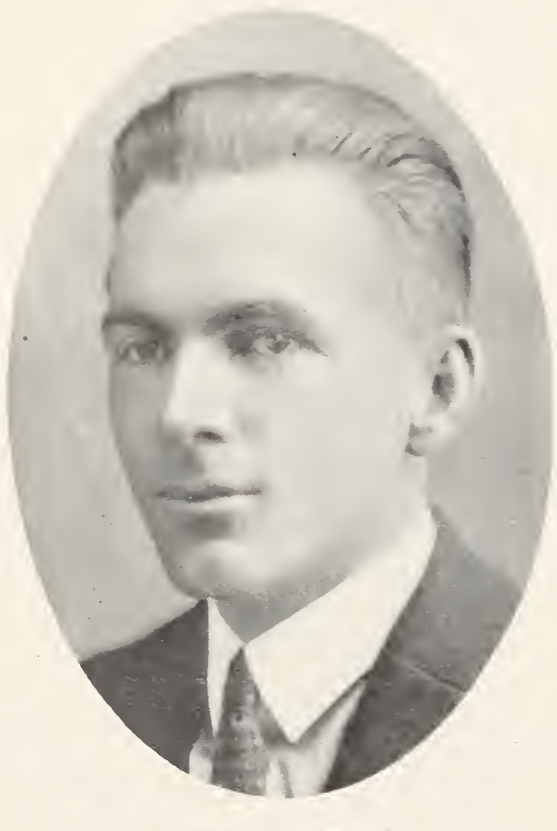

SAMUEL NEWSOM 
s
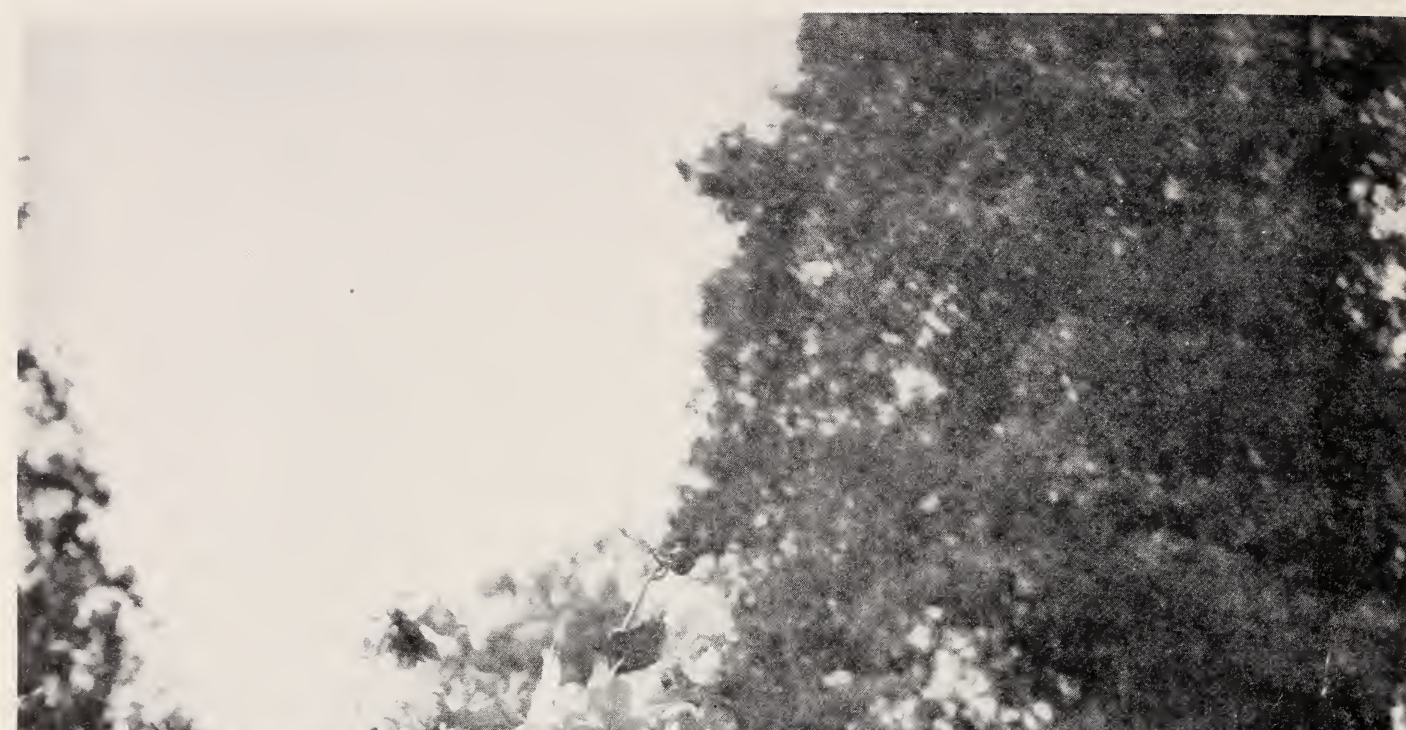

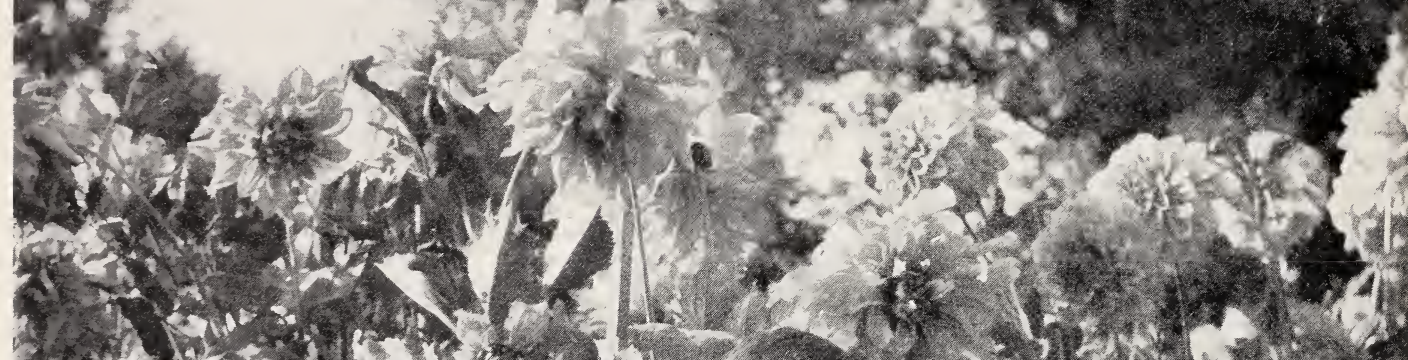

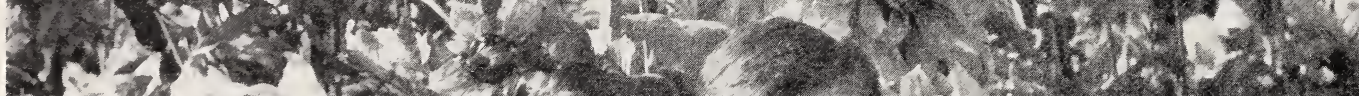

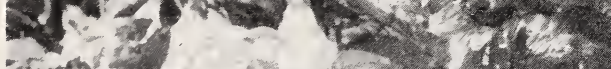
m.

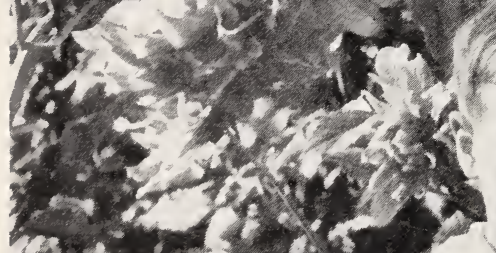

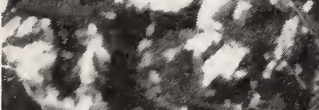

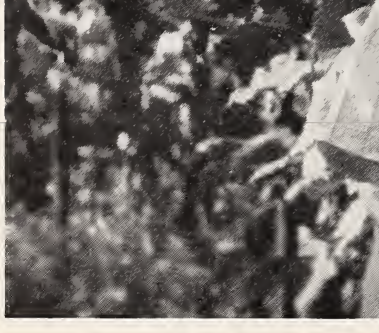
(16)

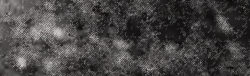

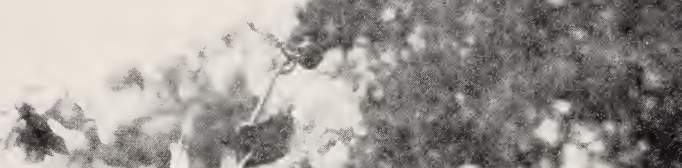




\section{Decorative Dahlias}

Decorative Dahlias are large and usually full to the center, with loosely formed, long, flat petals. Many new introductions are remarkably beautiful. Some of the best cut flower varieties are in this class.

$\star$ AIBONITA (Oh, how beautiful)-This is one of our largest originations. An immense flower of a lavender or violet pink, shading to white, with a rich golden yellow at base of petals. The formation is unusual, owing to the great depth and fullness of the flower. The long graceful stems hold the huge blossoms high above the foliage, producing an extremely showy effect. Have had many reports as to the success of this dahlia throughout the entire country. 1.50 .

$\star$ AL KORAN-A rery proud and handsome dahlia that is always admired in our gardens. The extra tall plants are very useful for background effects and are liberally covered with large blooms of golden rod and amber. The petals of this flower are wavy and the blooms are held high on long, strong stems. A most excellent rariety. $\$ 2.00$.

^ARROW OF GOLD-A refined blossom of pure gold, deepening in the center and shading to a golden apricot and amber at the outer petals. The immense deep blooms are held erect on long, stiff stems, making it a wonderful rariety for cutting and exhibiting. Since introducing this dahlia, we have received such excellent reports that we feel confident in recommending it most highly. \$2.50.

$\star$ AMLLET-A very beautiful and satisfactory variety, that blooms early and late, and is always covered with wonderfully fine blossoms. The color is very rare, a rich cleep brown, suffused with old rose and gold. The flowers are always large and deep and of the most perfect formation, while the bush is strong and vigorous. One of the most faithful and raluable varieties for all purposes, and should be in every garden. $\$ 7.50$.

$\star$ AMUN RA-Our Gold Medal dahlia is of glorious coloring, and one of the greatest prize winners. To ca!l it a glorified burnt orange hardly does it justice. The stems are wonderful-erect and stout and hold the immense blossoms well above the strong, vigorous plant. The blossoms keep for days when cut and last indefinitely on the bush. Amun Ra will be in flower long after many of the other dahlias have ceased blooming. This immense decorative of gorgeous shades of copper and orange will be more fully described and illustrated on page 15. \$1.00.

$\star$ BAZAAR-An extra large fine blossom that is a combination of California Sunset shades. Soft chrome yellow overlaid with red-delicately blended so neither predominates. This Autumn tinted flower, areraging nine inches has a good stem. and is fine for cutting and exhibition purposes. $\$ 2.00$.

$\star$ BEAL BRUMMEL-A pure royal purple which does not fade nor burn on the hottest day. The low, spreading bush is always covered with these rery attractive blooms, which are held high on excellent stems. A fine variety for all purposes. $\$ 2.50$.

$\star$ BERCEUSE-Something different, of pure salmon color early in the season, but changing later to salmon suffused with gold. Large flower with good stem. $\$ 1.00$.

$\star$ BLACK JACK-The color of this dahlia is so dark that it is almost black, though upon close inspection it will be found to be deepest maroon. A very striking variety that is liked by everybody. We always have a "Black Jack" planted at the beginning of our display garden because of this. The plant is very tall and the stems are perfect, holding the large flower's proudly erect. We can recommend this dahlia for all purposes. $\$ 2.50$.

BOSTON WHITE_A pure white decorative dahlia of Eastern origin. The flowers are of good size and the stems are perfectly erect and strong. $\$ 1.00$.

$\star$ BLLE LADY (One of our 1925 originations) - A large flower of an unusual shade of bluish lavender, where the blue, instead of the pink tints prevail. The petals, shading to white, instead of pink, give this dahlia a decidedly blue cast. This beautiful variety was greatly admired in our garden and always in demand as a cut flower. The fine, large blossoms are held high above a robust bush on strong, stiff stems. $\$ 2.50$

$\star$ CAROLYN WINTJENS-Beautiful salmon pink with rose shadings. Very large charming blossom with good stem. Excellent for exhibiting and cutting. 50c.

Dahlias marked $\star$ originated in California. 


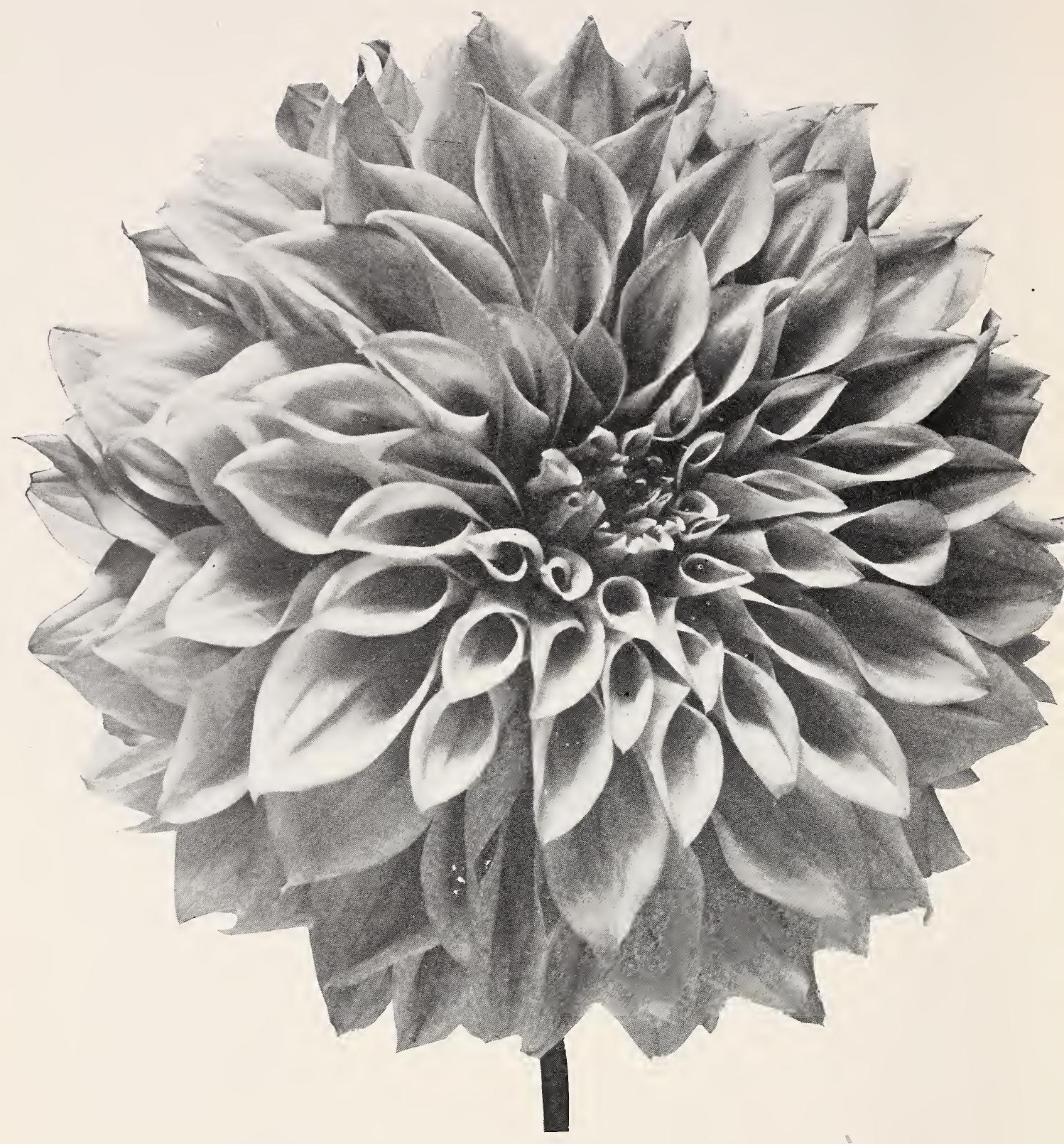

\section{Decorative Dahlia-Ellinor Vanderveer ONE OF OUR FINEST ORIGINATIONS}

This immense glowing, satiny rose pink decorative which helped us win the Palace Hotel Trophy Cup for the best collection of 12 California dahlias at the recent show, is said by many eastern growers to be the best dahlia ever originated in California. This year's cover design is a vase of Ellinor Vanderveer, exhibited at the recent Palace Show. (See page 8 for further description.) 


\section{Decorative Dahlias}

\section{Excerpts from Letters Received from Satisfied Customers Throughout the Country Concerning "Ellinor Vanderveer"}

"I also wish to congratulate you on putting out this season your very best dahlia to date, and one of the best that has come from the Coast-Ellinor' Vanderveer'. I grew this season forty rarieties from your state, including about all the best new rarieties and with me "Ellinor Vanderveer" was the star of the collection; such color, stems and formation! It was my best bloom in the winning collection of California varieties in two shows. The judges at the State Show announced it one of the best receired from the coast in recent years-that it is here to stay."-(From New Jersey.)

"Certainly I could not refrain from congratulating you on the wonderful success of the 'Ellinor Vanderveer'. I have had the opportunity' of seeing this dahlia growing in various parts of New England and the East this summer under varying conditions, and it certainly seems to be the outstanding California dahlia this year."-(from Connecticut.) vania.)

"I think 'Ellinor Vanderreer' is the finest dahlia in the world."-(From PennsIl-

"I have only the finest comments to make of 'Ellinor" Vanderveer'. This is one of the best blooming dahlias on the entire lot in Garden City. This dahlia has done well in other places here in the east, and I think you can safely count on getting somewhere on the roll of honor so far as the East is concerned this year."-(From New York.)

" 'Ellinor Vanderveer' is the finest thing ret with us; it is a magnificent plant."(From British Co'umbia.)

"Your 'Ellinor Vanderver' was a wonder; in fact, I think it was the rery finest variety I had in my garden. Size, stem, color, vigorous growth of bush and general habits were the very best; and it was the admiration and joy of all who saw it."(From Oregon.)

" 'Ellinor Vanderveer' is the best of the new California rarieties I have seen this rear, and I am not alone in that opinion, the color good, stem excellent, large blooms and a free bloomer."-(From New Jersey.)

" 'Ellinor Vanderveer' is a wonderful dahlia, throws a huge bloom and has wonderful stems. Keeping qualities rery fine. It has certain!y done well with me, and I consider it one of the good ones."-(From Oklahoma.)

"The bloom of 'Ellinor Vanderveer' won first prize as the largest California bloom."-(From New Jersey).

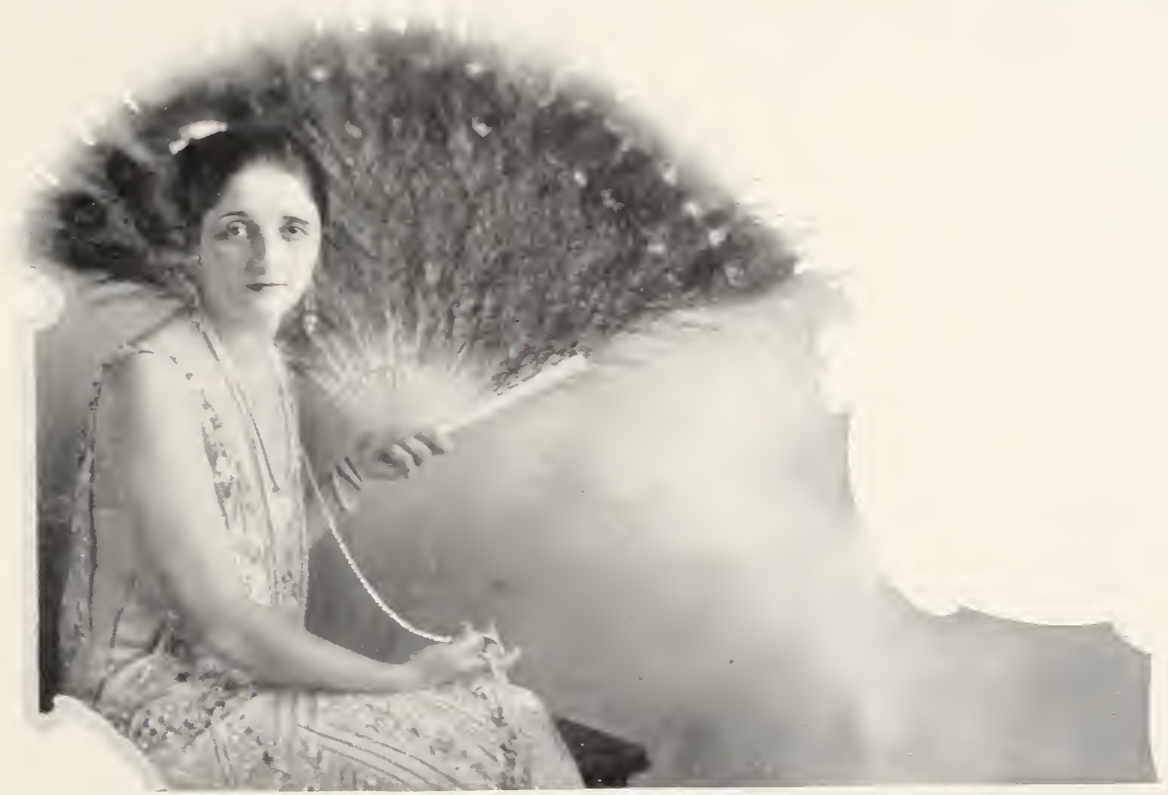

ELIINOR VANDERIEER, OLR BEALTIFLL FRIEND, FOR WHOM WE NAMED OLR DAHLIA 


\section{Decorative Dahlias}

$\star$ CHAMPAGNE-This immense novelty is one of the largest dahlias. The coloring is rare-warm autumn shades varying from burnished copper to a dull golden champagne and chamois. The stem is exceptionally long and strong and holds the massive flower absolutely upright high above the tall bushes. This is one of the finest of the California dahlias and should be in every collection of dahlias. Champagne was one of the dahlias that helped to win the Palace Hotel Trophy for us in 1924,1925 and 1926 . \$2.50.

$\star$ CHOU-Pink of the old fashioned rose, heavily shaded with white until the cool fall days when the flower is without shadings. Very deep and large and full centered at all times. The beautiful large flowers are held erect on long stiff stems. \$2.50.

$\star$ CONCHITA-A pink Rookwood without the lavender suffusion. The formation of this large, deep flower is irregular enough to be charming. Stems are long and stiff, held high over plants that grow moderately tall. In 1925 this dahlia was included in the collection of the Best Twelve California dahlias. \$3.50.

*CONSTANCY-One of the most dependable varieties in our gardens. Its color is a lively rich shade of deep, glowing pink. The flowers are very large, held erect over strong, sturdy bushes, on long, stiff stems. \$2.50.

$\star$ DIXIE-A lovely flower of salmon suffused with bronze, and one of the best cut flower varieties, having long, stout stems. \$2.00.

$\star D R$. TEVIS-A beautiful shade of soft salmon rose, suffused with old gold, shading to a golden apricot center. One of the largest grown; flowers nine to eleven inches in diameter; the immense flowers being held erect on fine, long, vigorous stems. 75c.

$\star$ EARLE WILLIAMS-This very large blossom, of brilliant crimson and white well distributed in the petals, stands erect on long stiff stems. Sometimes a blossom will come crimson, tipped white. $\$ \mathbf{1 . 5 0}$.

ઐEILEEN ROXBOROUGH-(One of our 1927 introductions). A stately bloom held proudly erect on a stiff, cane-like stem. The coloring is an intense rosy pink, with a suffusion of mauve and gold. The large blooms are exceedingly attractive in the garden, having a rich, glowing effect, and owing to their unusual keeping qualities and excellent stems, can not be excelled as cut flowers. $\$ \mathbf{\$ 5 . 0 0}$.

$\star$ EL DORADO (One of the finest novelties)-An immense blossom of vivid gold, deepening in the center. This exceptionally fine dahlia of great substance stands well out of the foliage of a low growing bush, on strong erect stems, making it not only an exhibition variety but an excellent cut flower. We have had fine reports of this dahlia. $\$ 5.00$.

«ELLINOR VANDERVEER-One of our 1925 originations that has been a great success and prize winner throughout the country. An incomparable dahlia of exquisite beauty and great size. The large blossoms of glowing, satiny rose pink are of great depth and substance and are held far above a tall sturdy bush on exceptionally long, stiff stems. There is no surplus leafage and with ordinary disbudding every flower is perfect. This dahlia is said by many to be the best California dahlia ever put on the market, as shown from the excerpts on page 7 . Ellinor Vanderveer was included in our collection of Prize Winning California dahlias at the recent Palace Hotel Show. \$5.00.

$\star$ EMBASSADOR--Very large blooms of deepest shade of red or maroon, and if grown in the shade are nearly black. Free blooming; stems long and stiff. 50c.

*EVELYN ADAMSON-The color of this immense and exquisitely charming dahlia is so unusual it is difficult to describe. A rosy fawn pink suffused with gold, growing more beautiful as the blossom matures. This enchanting flower, very large yet refined, is held on a long graceful stem. $\$ \mathbf{1 . 0 0}$.

$\star$ FAITH GARIBALDI-The Gold Medal Dahlia introduced by Bessie Boston in 1925 and won for her First Prize for best twenty-five blooms in our recent show. This immense, deep rose decorative is a flower of great substance and of perfect formation. It does not require heavy disbudding for immense blooms. The stem is exceptionally strong and carries the flower high above the foliage. The blossoms last indefinitely on the bush and nearly a week in the house. This dahlia has won many prizes in different parts of the country and was included in our twelve best California dahlias at the recent show. $\$ \mathbf{5 5 . 0 0}$. 


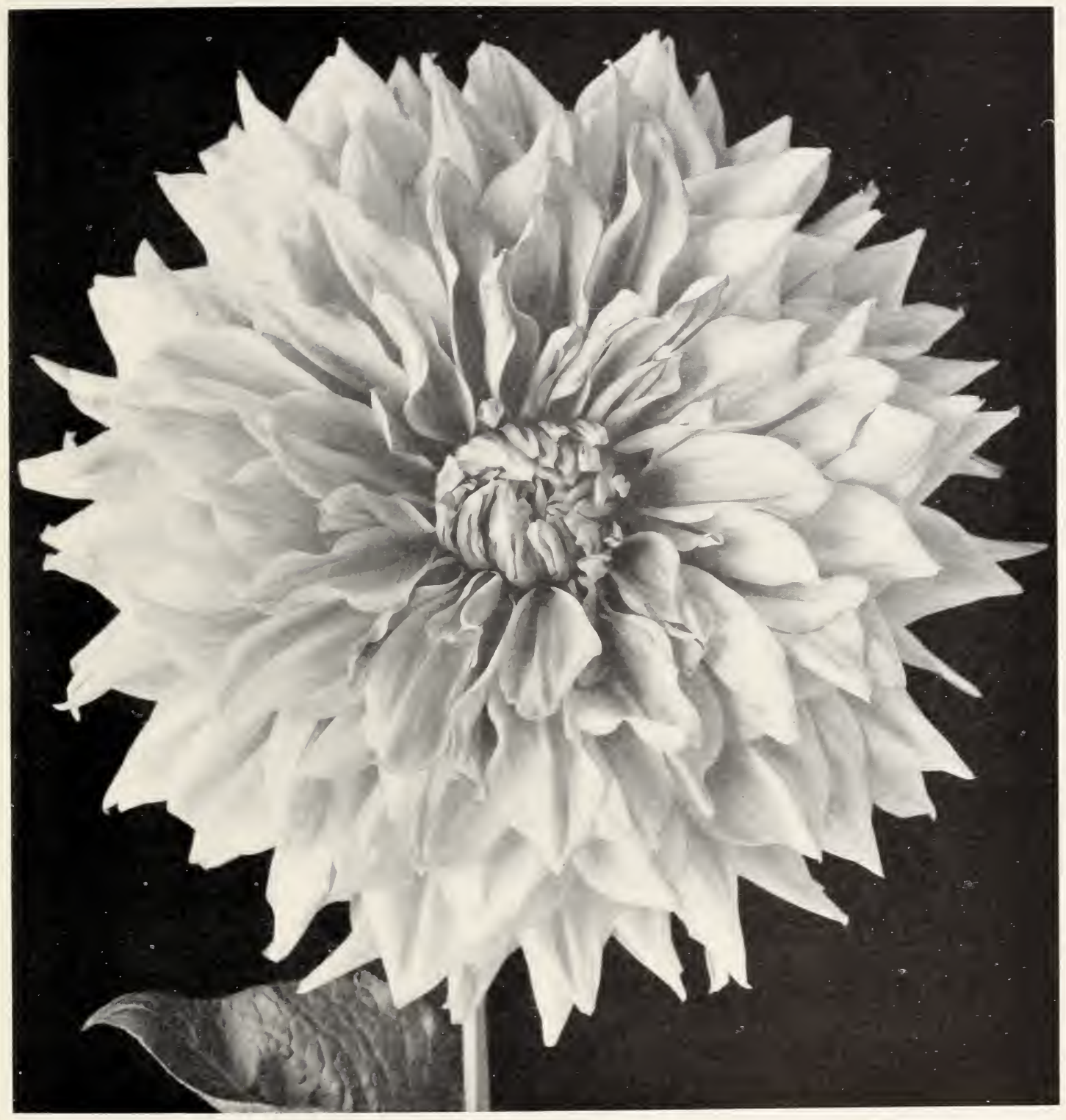

Decorative Dahlia-Shirley Oliver

This immense light rose pink is a fine exhibition and garden flower and maintains its size the entire season. (For further description see page 18.) 


\section{Decorative Dahlias}

$\star$ GLADYS ROLANDS-(One of our 1927 introductions.) A lovely flower of an extremely odd and beautiful coloring. In fact, no description can half convey its beauty. The base color is lavender, but this is almost hidden with a heavy suffusion and veining of reddish purple. The stems are perfect and hold the large, very deep blossoms proudly erect on a tall, well branched plant. A variety that is truly different. $\$ 5.00$.

*GLORIANA-Pure old gold, heightened by a slight reddish glow in the center. This is an exceedingly fine large flower with long stiff stems, which blooms freely all season. $75 \mathrm{c}$.

$\star$ GOLDEN FLEECE-One of our finest 1926 introductions. An exceptionally magnificent blossom of a rich, creamy, golden yellow with a satiny sheen, frequently tipped with white giving it a silvery frosted appearance. Due to the great demand for this variety we have been forced to withdraw it from the market to increase our stock. We hope to have sufficient to offer it again next year. $\$ \mathbf{\$ 1 0 . 0 0}$.

$\star$ GORDON BLANDING-A lovely new dahlia of soft pastel shades. The outer petals of the flower are deep pink at the base and lighter pink at the tips, while the center of the blossom gradually lightens to a creamy white, with the faintest suffusion of pink. A very attractive variety with good stems that is always in bloom. \$2.00.

\#GRENADIER-This dahlia, of huge size and depth, with slightly quilled petals, is purplish maroon on one side and silver on the other, but both colors show-a very unique effect. The stems are long and strong, and the bush always is covered with blooms. \$5.00.

*HALVELLA-One of the most charming varieties in our garden. A beautiful rose pink flower of huge size and perfect formation, held erect on perfect stems. Visitors are captivated by the irresistible beauty of this dahlia, which is always in bloom and one of our best cut flower and exhibition varieties. $\$ \mathbf{2 . 0 0}$.

$\star$ HARRY DAVIDSON-A very pleasing variety of mulberry shadings. The flowers are large, stems fine, and the bush quite tall and always in bloom. $\$ 1.00$.

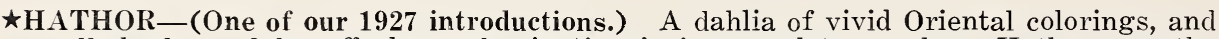
all the lure of far off places, fascinating in its complete novelty. Hathor was the Egyptian Goddess of Love, Mirth and Social Joy, and this dahlia fittingly symbolizes these qualities. The predominating color is flame-not red, but verging on deep crimson, orange, and all those colors seen in glowing embers. The formation is always perfect and the stem exceptionally fine and stiff, so the large bloom looks one squarely in the face. Hathor has won a first prize. \$7.50.

JERSEY'S BEAUTY--A justly praised Eastern variety, originated by W. H. Waite, of striking loveliness. A perfect bloom of an exceedingly live, deep, true pink, carried high above the foliage on perfect stems. The plant is vigorous and a tall grower. A fine dahlia for that deep pink note, so often missing in gardens. A famous prize winner. $\$ 2.00$.

*JESSIE K. PRESCOTT-A beautiful large flower of an unusually lovely coloring, deep orange at the center, gradually shading to creamy orange on the rows of outer petals, and illuminated with a violet glow. The bushes are tall and branching. The flowers have exceptionally long, good stems. $\$ 2.00$.

JOHN ALDEN-A fine, upstanding variety of a color greatly in demand. The large flowers are of a true purple, held perfectly erect above a fine, sturdy bush. \$1.50.

JOHN DOE OF OZ-A large blossom of pale yellow, with a faint suggestion of orange. The flowers have great depth and fine formation. The plant is tall and robust and the stems are excellent. A beautiful cut flower or garden plant. 75c.

JUDGE MAREAN-In this large dahlia there is a riot of blending color, ever changing as the flower ages. There is a glowing salmon pink, iridescent orange, yellow and pure gold, and the shades all blend most beautifully. The large fine flower stands on a long, straight, strong stem facing the garden boldly. \$1.50.

$\star J U N I O R-O n e$ of our originations that has made a sensation throughout the country. An enormous flower of pure lavender, the centers remaining closed throughout the entire season. This huge blossom is a seedling of the Millionaire, but has greater width. Junior is truly wonderful in the garden and as a flower to be used in competition in the largest-dahlia class, having won several first prizes in different parts of the country. $\$ 1.50$. 


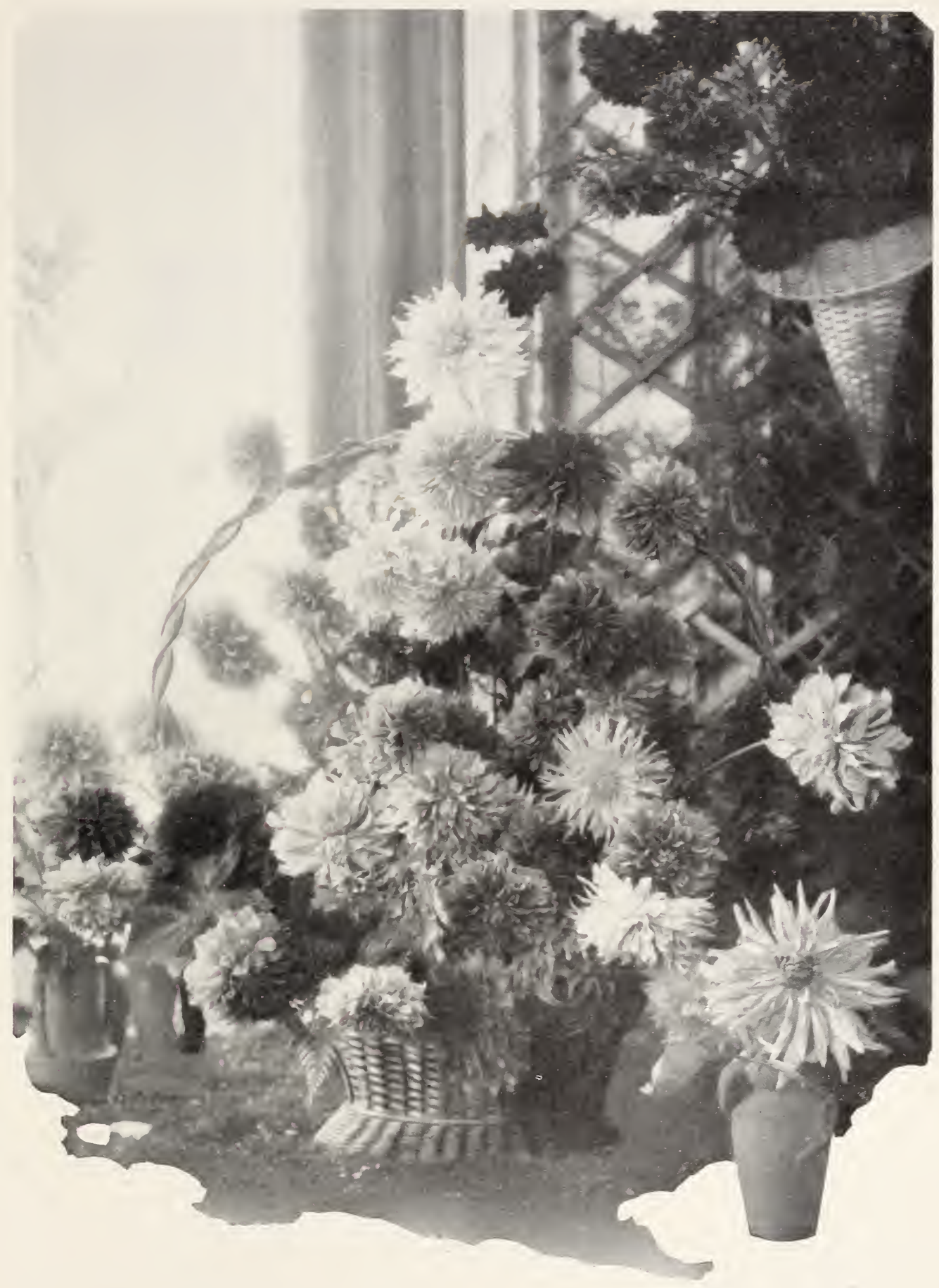

\section{The Beautiful First Prize Basket of California Dahlias}

This was one of the most attractive features of our exhibit and was made up of the following Autumn tinted Dahlias: Hathor, M. H. de Young, Sunny California, El Granada, El Dorado, King Tut, Amun Ra, Talisman, Rollo Boy, Champagne and Bazaar. The immense dahlia in the vase is Siskiyou. 


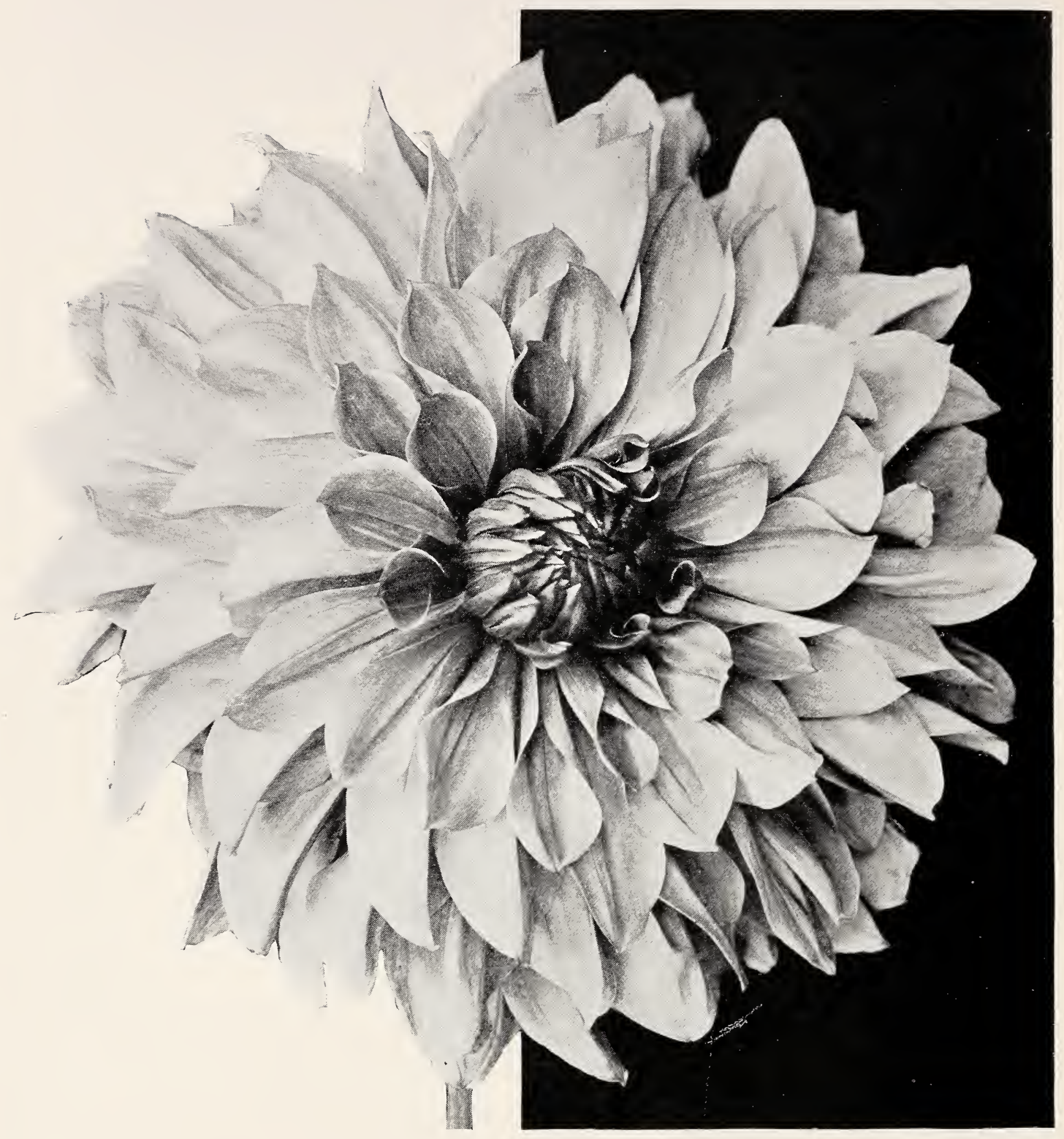

\section{Decorative Dahlia-Kittie Dunlap}

This Prize Winner is a delightful new shade of American Beauty Rose, having excellent keeping qualities, long stiff stem, immense size, and perfect formation. It is not only a beauty, but has every characteristic which endears it to a Dahlia lover. (See opposite page for further description.) 


\section{Decorative Dahlias}

$\star J$. W. DAVIES-The coloring of this beautiful dahlia is difficult to describe; the deepest shade of cerise at the center, graduating to a lighter tint. This blending of the two shades creates an entirely new effect. The immense flower has depth as well as size and the stem is perfect, making it as good for cutting as exhibiting. It blooms profusely all the season. One of the most admired dahlias in our garden and was included in our twelve best Californians. $\$ 2.50$.

$\star$ KING TUT-One of our 1926 originations. An extra large blossom of rich, dark, velvety, glowing, crimson burgundy, of fine formation and with closed centers throughout the season. One of the most admired dahlias in our garden. Indispensable for the darker tones that add richness to a combination of dahlias, especially the autumn shades. The large, fine blossoms of great substance are held high above strong, medium tall, bushes on extra long stiff stems. King Tut is one of our finest cut flowers, and was included in our collection of Best California Dahlias. Large vases of this dahlia greatly enhanced the beauty of our display both in 1925 and 1926. $\$ 5.00$.

*KITTIE DUNLAP-A delightful new shade of American beauty rose. This beautiful dahlia which has been a consistent prize winner throughout the entire country, is a very large flower of perfect formation. The long stiff stems, and excellent keeping qualities make it indispensable as an exhibition as well as cut flower variety. A bloom of this remarkable variety was sent by Air Mail to the American Dahlia Show in New York, and lasted four days after its arrival. Our display is never complete without a large vase of this superb dahlia. Kittie Dunlap won us a gold medal for the Best Fifty Blooms at the 1926 Palace Hotel Show. \$1.50.

ネKLAMATH BEAUTY-Another of our 1926 introductions of an extremely novel and pleasing color. Good sized flower is of an iridescent rosy pink, shading lighter towards the center, which has a suggestion of yellow. This charming blossom is held high above a sturdy bush on a long, erect stiff stem. It was much admired in our garden for its unusually beautiful coloring. $\$ 1.50$.

LADY BETTY - This very lovely dahlia is a creamy white, but a pinkish suffusion is spread as a haze over the flower. A large, fine flower produced on strong stiff stem. One of the best Marean dahlias. \$2.50.

ÆLEAH M. GLEADELL-Copper illuminated with gold. A large beautiful dahlia and a splendid keeper with a fine long stem. Blooms freely on 'all luxuriant bush. This dahlia was originated by Mr. J. W. Gleadell and was among our best Californians in $1925 . \$ 3.00$.

^LOGAN'S WHITE-A most excellent pure snow white dahlia without a tinge of any color. The blooms are large, and are held on long, stiff stems. The bushes are always covered with blossoms. \$1.50.

ઐ MARJORIE HENNESSEY - (One of our 1927 introductions.) An exceptionally lovely dahlia with every good quality. The blooms are large, of the most perfect formation, and are carried on extra long, stiff stems high above a tall growing bush. The color is most attractive-Amber, heavily suffused rose, lightening toward the center to a true amber. The tips of the unfolded petals are of a deep rose pink, producing a very beautiful effect. $\$ 7.50$.

(See illustration on page 4 )

MARMION-(Oregon Novelty.) Truly, among the very largest in our garden. Most flowers are dwarfed when placed near it. The color is pure golden yellow, with bronze suffusion on reverse of peta's and a deeper bronzy tone on the high center, and outlining each petal. The stems are good, and hold the immense blooms gracefully above the sturdy plant. Marmion is an excellent variety for the "Largest Dahlia in Show" competition. \$10.00.

\#MEADOW LARK-A fine large flower of a new coloring. It has shadings of buft and straw, with the reverse side of the florets darker. This large sized flower is held high on extra long, straight stems, out from a tall plant with vigorous foliage. $\$ 3.50$.

MEPHISTOPHELES-Ruby-red, showing small golden yellow points at the end of some petals, thereby enhancing its beauty. This large Dahlia is held erect on a long, unusually stout stem. Very highly recommended, as it is different. $\$ 2.00$. 


\section{Decorative Dahlias}

$\star$ M. H. DE YOUNG-A beautiful blossom of pure old gold with scarcely any variation in color, except perhaps the center is illuminated with a slightly brighter shade. This exceedingly attractive flower is an invaluable addition to the Autumn colored dahlias so much in demand. The large flower is held high on absolutely stiff stems, growing far out of the foliage. An excellent variety for exhibition and cut flowers. $\$ 5.00$.

$\star$ MISS CALIFORNIA-(New 1926). A large, perfectly formed, and very beautiful blossom of the new shade of Oriental Fuschia. The plant is tall and hardy, the stems perfect and exceptionally long so the large blooms are held proudly erect and look one squarely in the face. An excellent flower for exhibition, cutting, or garden effect. Miss California won First Prize as a Seedling at the California State Floral Society, 1925 . $\$ \mathbf{\$ 5 . 0 0}$.

MORDELLA-One of the best of the newer dahlias. A real art dahlia of a bright apricot buff color, although it is infinitely more beautiful than the description. The flowers are large, and are held well above a tall growing plant on excellent stems. Mordella is a great favorite, and helped us to win the Gold Medal for the "Best Display of New Jersey Dahlias", at the recent Palace Hotel Show. \$3.50.

ŁMRS. CARL SALBACH-Is still a favorite, and is one of the really great dahliasa success wherever grown. An immense bloom of a lovely mauve pink, shading lighter to the center and every petal outlined in deep mauve. The stems are extremely long and strong, holding this immense blossom proudly erect above a tall, vigorous plant. $75 \mathrm{c}$.

MRS. ETHEL F. T. SMITH-Creamy white, shading to a lemon tint in the center. The flowers are huge, and the bushes are always covered with them. The stems are extra strong and fine. 75c.

$\star$ MRS. CHARLES CHASE-One of the most beautiful really pink dahlias. The color of this lovely flower has been likened to the enchantress pink carnation, and is exquisite under artificial light. The blossom of good size, is held erect on long stiff stems, and is a most desirable cut flower. $\$ 2.50$.

$\star$ MRS. E. C. BOSTON-A fine white decorative. Regularly formed flowers with good stems. Does well in every locality. $\$ \mathbf{1 . 0 0}$.

MILLIONAIRE-This is undoubtedly one of the largest dahlias grown. Most delicate lavender with a faint pink cast overshadowing it. The immense bloom of unusual depth stands erect on its still stem and is an extremely valuable cut flower. This dahlia has won many prizes in the largest dahlia class. 75c.

MRS. I. DE VER WARNER-This exquisitely beautiful blossom of soft orchid, or rich rosy mauve, is one of the most admired in our gardens and the best of the Marean dahlias that we have grown. This extra large refined, lovely flower with its long stiff stem, is a prolific bloomer and one of the very best for cut flowers as well as exhibition purposes. 75c.

$\star$ MURIEL-One of our 1926 originations and a fine cut flower variety of good size. In color a charming, clear baby pink. This beautiful blossom has fine long stiff stems growing out of a sturdy bushy plant which must be well thinned out and disbudded if you wish large blooms, as it is very floriferous. To one loving delicate colorings this is very appealing. $\$ \mathbf{2 . 5 0}$.

$\star$ NOBILIS-Our garden is never complete without a row of Nobilis, as it is so bright and attractive. The flowers are of brilliant crimson, tipped white, and coming in all possible combinations of the two colors. It is almost a counterpart of Earl Williams. Visitors invariably exclaim over the beauty of this variety, especially the men, who like the bold, large flowers on their dandy stems. \$1.50.

$\star$ OASIS-A delightful true pink, without any trace of yellow or lavender. A large, but not heavy flower, held on long, graceful stems. The low plants are always covered with these large and attractive blossoms. $\$ \mathbf{4 . 0 0}$. 


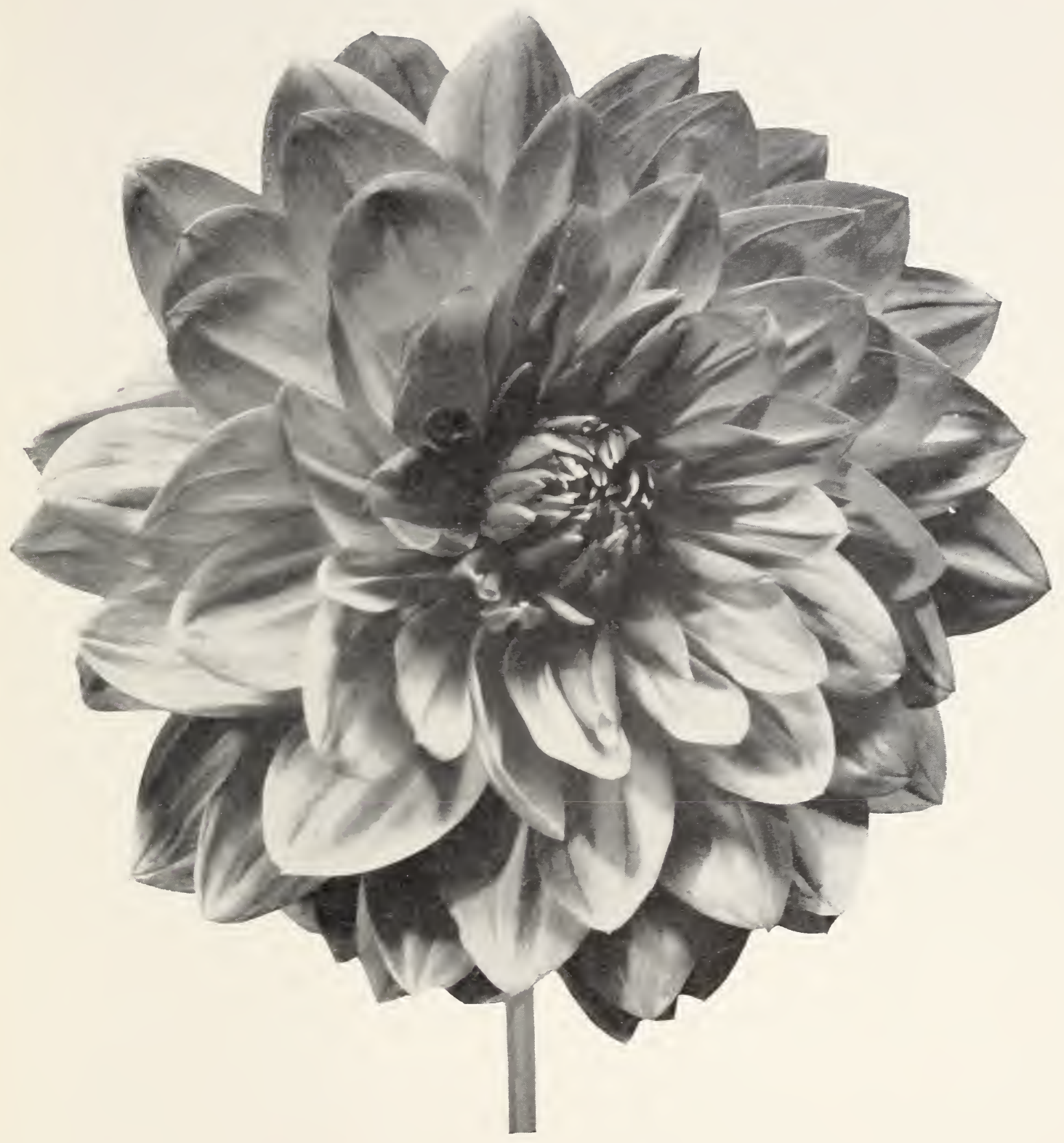

\section{Decorative Dahlia-Amun Ra}

The above Gold Medal Decorative Dahlia is of gorgeous shades of copper and orange, shading to gold and amber, and deepening in the center, to a rich, dark, reddish bronze. An Eastern grower says that Amun $\mathrm{Ra}$ is an unusual color, which almost seems as if it has a real light of some kind to make it glow. This dahlia is one of the greatest prize winners and unexcelled as a cut flower. For further description, see page 5 . 


\section{Decorative Dahlias}

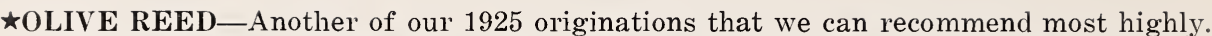
This remarkable dahlia of mammoth size, is of a clear and pure shade of yellow, ard has held the attention of visitors to our garden, who declared that although they did not generally care for yellow dahlias, this one appealed to them. We have had fine reports from this dahlia that it has created a sensation in many gardens. The massive blooms of great substance, are held erect high above a vigorous bush, on strong, rigid stems. $\$ \mathbf{\$ 7 . 5 0}$.

$\star$ PATTY JANE-One of our 1926 originations. This lovely bright rose pink blossom with its pale delicate pink center, is a seedling of Mrs. Carl Salbach, and has all its good qualities. A large flower with long, fine erect stems, and an excellent cut flower variety. We always use Patty Jane in pink baskets at the different dahlia shows. $\$ 2.50$.

^PEERLESS-An exceptionally fine clear sulphur yellow blossom of large size, great depth, and regular formation, standing erect on a hard, stiff stem. The bushes are always a mass of bloom. $\$ 2.50$.

$\star$ PIONEER-A large blossom of dark mahogany red. These richly colored blooms, produced in profusion, have long and wiry stems. The ornamental foliage of dark bronze green blends well with the unique shade of the flower. $\$ 2.50$.

$\star$ PRIDE OF CALIFORNIA-A very large crimson red decorative with a full dark center that has never been surpassed as a good keeping cut flower. Very prolific. Extra long, stiff stems hold blooms erect above tall bush. 50c.

$\star$ PRINCESS PAT-A magnificent decorative of a glorious shade of old rose deepening at the center. The large flowers grow well above the foliage on long, stiff stems. Under artificial light this variety is exceptionally beautiful. 75c.

PROXIE-A beautiful flower of deep rich red, held above a tall growing bush on a fine stem. An excellent cut flower and exhibition variety. $\$ 1.00$.

$\star$ REALIZATION-This large canary yellow decorative is one of the first dahlias to bloom in our garden and is covered with flowers throughout the entire season. Fine stems and a sturdy bush. $\$ \mathbf{1 . 0 0}$.

ROBERT TREAT-This beautiful Eastern introduction has been one of the greatest prize winners wherever exhibited in that part of the country. This immense bloom of American Beauty rose color has great substance and is held erect on long strong stems. Robert Treat is an exceptionally handsome variety and is always very popular in our garden. $\$ 2.50$.

$\star$ ROOKWOOD_A most beautiful dahlia, that has been a persistent prize winner, ever since its introduction. The color is pure bright cerise rose, without the faintest touch of magenta, and is as beautiful under artificial light, as the Russell rose. The immense flowers are held far above the low growing and spreading bushes on long, excellent, stiff stems. This was one of the best twelve Californians in 1925 . $\$ 3.00$.

$\star$ RORY O'MORE-A striking fancy of deep maroon, tipped white. Large flowers, and perfect stems. A very attractive variety, especially in the garden. \$3.50.

$\star$ ROSA NELL_Clear bright rose, a rare color in dahlias which attracts immediate attention. This immense bloom is one of the very largest, and is held high above a strong, vigorous plant on extra long stiff stems. This is a great favorite. $\mathbf{7 5}$ c.

ROSE FALLON-(Novelty.) One of the largest of the new Eastern introductions. A truly magnificent decorative of pleasing shades of amber, russet, and salmon. The formation is perfect, and the stems are excellent. The foliage of this beautiful variety is very dark and handsome. Rose Fallon is a wonderful keeper, and lasts for days when cut. This dahlia can easily be shown in the largest bloom class. $\$ 10.00$.

SAGAMORE-A large, perfect flower, of pure gold, deepening toward the center to a rich reddish apricot. The stems are fine, and hold the exceptionally deep and full blooms perfectly erect. Sagamore is a fine variety for the gold effect in Autumn baskets. $\$ 3.50$. 


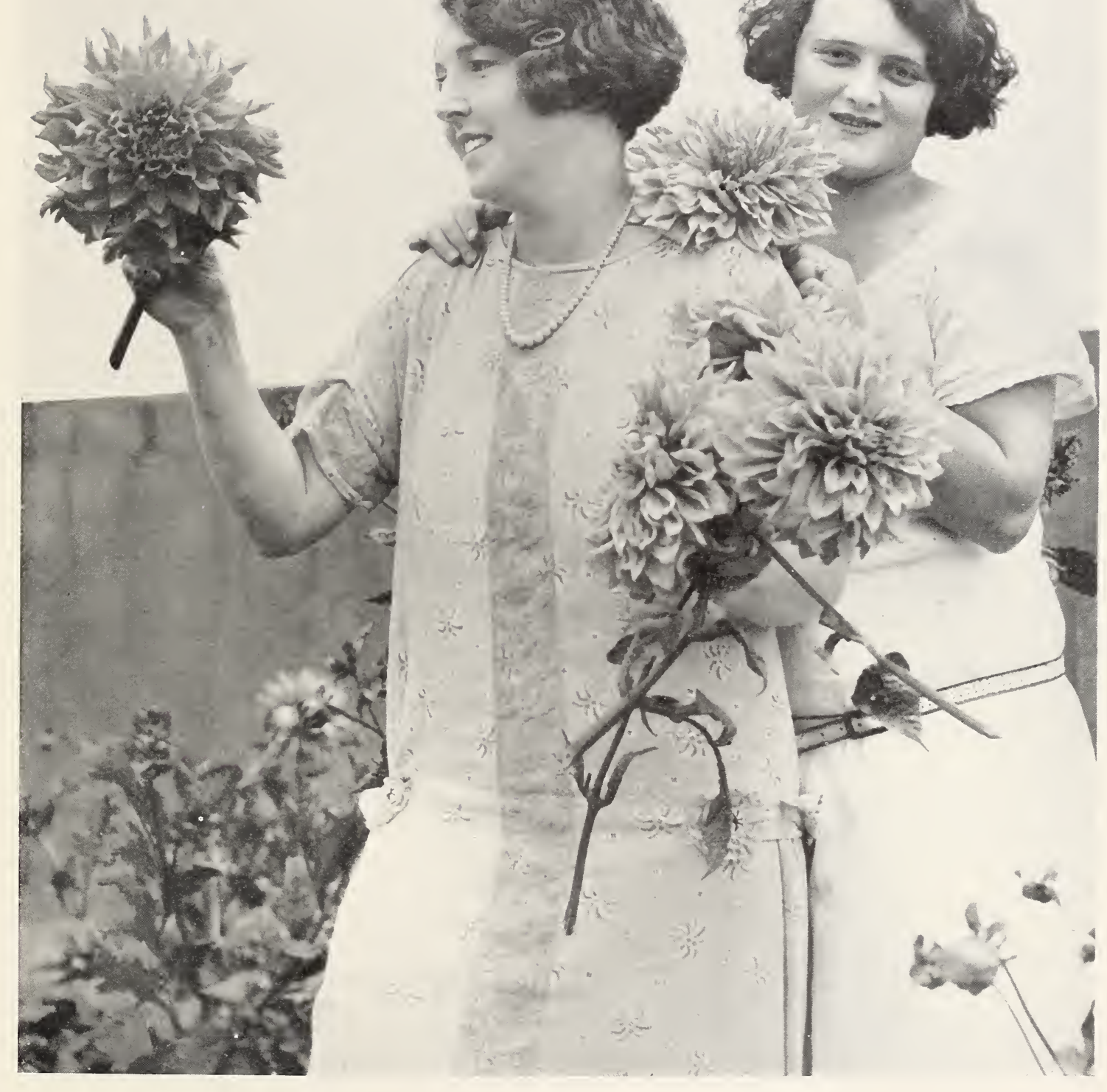

\section{Beauties Seen in Our Garden}

One of the young lady visitors to our garden is admiring our yellow decorative "Olive Reed", the other young lady to the right is holding our light rose decorative "Shirley Oliver". The large dahlia below, facing right, is our rose pink decorative "Ellinor Vanderveer". 


\section{Decorative Dahlias}

^SALBACH'S WHITE-The most perfectly formed white dahlia we have ever grown. Its unusually perfect formation and waxy appearance make it an outstanding and much admired varitey. The stems are perfect and hold these fine, large white flowers proudly erect. $\$ \mathbf{1 0 . 0 0}$.

$\star$ SCOTTISH CHIEF_-An unusual shade of golden cocoa or an amber coloring. Sometimes the blossoms are tipped with white, deepening into pink. Stems are long and strong. 50c.

$\star$ SERPOLETTE-A lovely flower of bright mauve with a prevailing pink tone. The large, full blossoms are held perfectly erect on fine stems. This beautiful dahlia is an excellent variety for all purposes. \$1.50.

$\star$ SHIRLEY OLIVER-One of our 1926 originations. This beautiful blossom of immense size is of a lovely light rose pink, with yellow at base of the long petals. This fine flower is held proudly erect on exceedingly long, straight stiff stems. We have received many good reports of this dahlia from the East where we sent it for trial. \$3.50. See illustration on page 9 .

$\star$ SHOWER OF GOLD-Brilliant yellow, deepening to soft apricot towards the center. A new type with slightly fluted petals. Large, strong stems. \$1.00.

$\star$ SHUDOW'S LAVENDER-If you love delicate tones, there is no more beautiful flower than this lovely silvery lavender, slightly shading to white. This exquisitely beautiful flower with a long, stiff, erect stem is held high above an attractive lace-like foliage on a tall growing plant, that is an ornament to any garden. A true decorative that never shows a center. No exhibit is ever complete without one or more of these charming flowers, and is always in demand as a cut flower. At our 1925 show Shudow's Lavender won first prize as "the most beautiful and perfect dahlia", and helped us not only to win the Palace Hotel Cup for the Best Twelve Californians, but the American Dahlia Society's Silver Medal for the vase of fifty blooms. $\$ 2.00$.

$\star$ SISKIYOU-A truly sensational dahlia that grows to immense size without any effort whatsoever. One of our customers calls it her "prize fighter" as it invariably wins First Prize whenever shown in the "largest dahlia" class. We have grown Siskiyou to fourteen inches in diameter. The stems are stiff as rods, and the flower is a very attractive pink, with a suggestion of mauve. This dahlia was also included in our twelve best Californians. $\$ 2.50$.

$\star$ SOLE MIO-(Novelty). Without doubt among the largest yellow dahlias we have ever grown. The color is a rich, deep yellow, with a suggestion of apricot. The stems are perfect and hold the immense flowers boldly above the strong, low growing bush. Sole Mio always receives much favorable attention in our garden, and adds greatly to any exhibit. $\$ 5.00$.

$\star$ ST. BERNARD_A huge flower of soft creamy white, suffused with a clear pink. Has a very good stiff stem, and is excellent for exhibition. $\$ \mathbf{1 . 5 0}$.

$\star$ ST. FRANCIS--Soft cream color, brightened with a pinkish glow on the outer petals. A delightful blossom, good for all purposes, especially as a cut flower, due to its large size and fine keeping qualities. The stems are perfect and the bush is always in bloom. $\$ 2.00$.

*SUFFRAGETTE-A large canary yellow decorative that is always in bloom. Occasionally a blossom will appear with white tips. The stems are fine and the bush is tall and robust. $\$ \mathbf{1 . 5 0}$.

$\star$ SULTAN, THE (One of our 1925 introductions) - The color of this attractive dahlia made it one of the most conspicuous in our garden, being a bright, true red. The good sized flowers are held well above the bushes on long, fine stiff stems. There is always a demand for a good red cut flower. $\$ 1.50$.

*SUNNY CALIFORNIA-A glorious combination of old gold, suffused with various shades of orange and red. The flower has a metallic lustre which heightens its beauty. In several recent exhibitions we displayed a large Oriental chest, and many Sunny California blooms were invariably used to produce a very rich effect in combination with other blending dahlias. The stems are fine and hold the flowers erect above a tall plant. $\$ 2.50$. 


\section{Decorative Dahlias}

$\star S L S A N$ G. TEVIS-An exceptional dahlia with a distinctive new color tone of a deep shade of lilac with a bluish sheen. A very graceful bloom of fine depth and great size held high above a vigorous plant. The stems are long and strong. $\$ 3.00$.

$\star$ THE GRIZZLY - This great shaggy dahlia of immense size, and of dark maroon red, has been a wonderful prize winner. Long strong stems, and a tall bush. \$1.00.

«TOMMY ATKINS-Without doubt the most startling dahlia in our garden. Huge flowers of flaming scarlet that fairly glisten in the sunlight. Everybody likes it as it is so different and no color approaches it in vividness. The stem is very stiff, like a cane and the blooms are held proudly erect, so that the name is exceptionally appropriate. $\$ 2.50$.

TRENTONIAN-One of Fisher \& Masson's finest originations that helped us to win a Gold Medal for the Best Collection of New Jersey dahlias. A giant decorative dahlia of a shade that appeals and captivates, and is really symbolic of Autumn. A wonderful blending of old gold, amber, and coppery bronze, the whole forming a flower of marvelous brilliancy, with a center of reddish bronze. The stems are perfect-long, and strong, and hold the large blooms proudly erect above a very husky and handsome bush. We can recommend this variety for all purposes. \$3.50.

$\star T R Y P H I N N I E-A$ lovely flower of bright shell pink, shading lighter at the tips of the petals. At the base and throughout the petals is seen a bright golden yellow. The reverse of the petals is a rich pink, giving the flower a decidedly new color. The stem, rigid and strong, lifts this good-sized blossom high above a low-growing plant. One of our best exhibition as well as cut flowers. \$1.00.

U. S. A.-This magnificent mammoth dahlia is a deep orange-that very unusual color so hard to attain in a dahlia, and the color most in demand by flower lovers. It is very free blooming dahlia with a fine long stem. A great favorite. \$1.50.

ॠ VALNTINE-A novelty of tremendous size and a lovely color of pure cerise. A truly wonderful exhibition and garden flower. The blossom sometimes is too heavy for the stem, due to its great size. In the largest dahlia class. \$1.00.

$\star W$. E. COOPER-A clear true pink with no suggestion of lavender or mauve. The blossoms are carried in profusion on perfectly rigid stems. We have had many fine reports of this dahlia throughout the East. \$1.50.

$\star W I Z A R D$ OF OZ-The color of this veritable giant of a dahlia is a rare shade of glowing amber pink, or soft salmon shades. The imrense blossom is held above the foliage with a fine, upright stem. In some localities it has a slight tendency towards the Cactus type. This remarkable dahlia of beautiful coloring is a raluable exhibition as well as a cut flower. $\$ 3.00$.

$\star$ WOOZY OF OZ-A large beautiful blossom of creamy pink with a suggestion of deeper tones of rose pink. The formation is very attractive. Fine, long, upright stiff stems. $\$ 1.00$.

If you do not find the varieties you wish in this selection, write us. We have many dahlias of which stock is too limited to list.

We shall be very pleased to render every assistance possible to those interested in the culture of the Dahlia. 


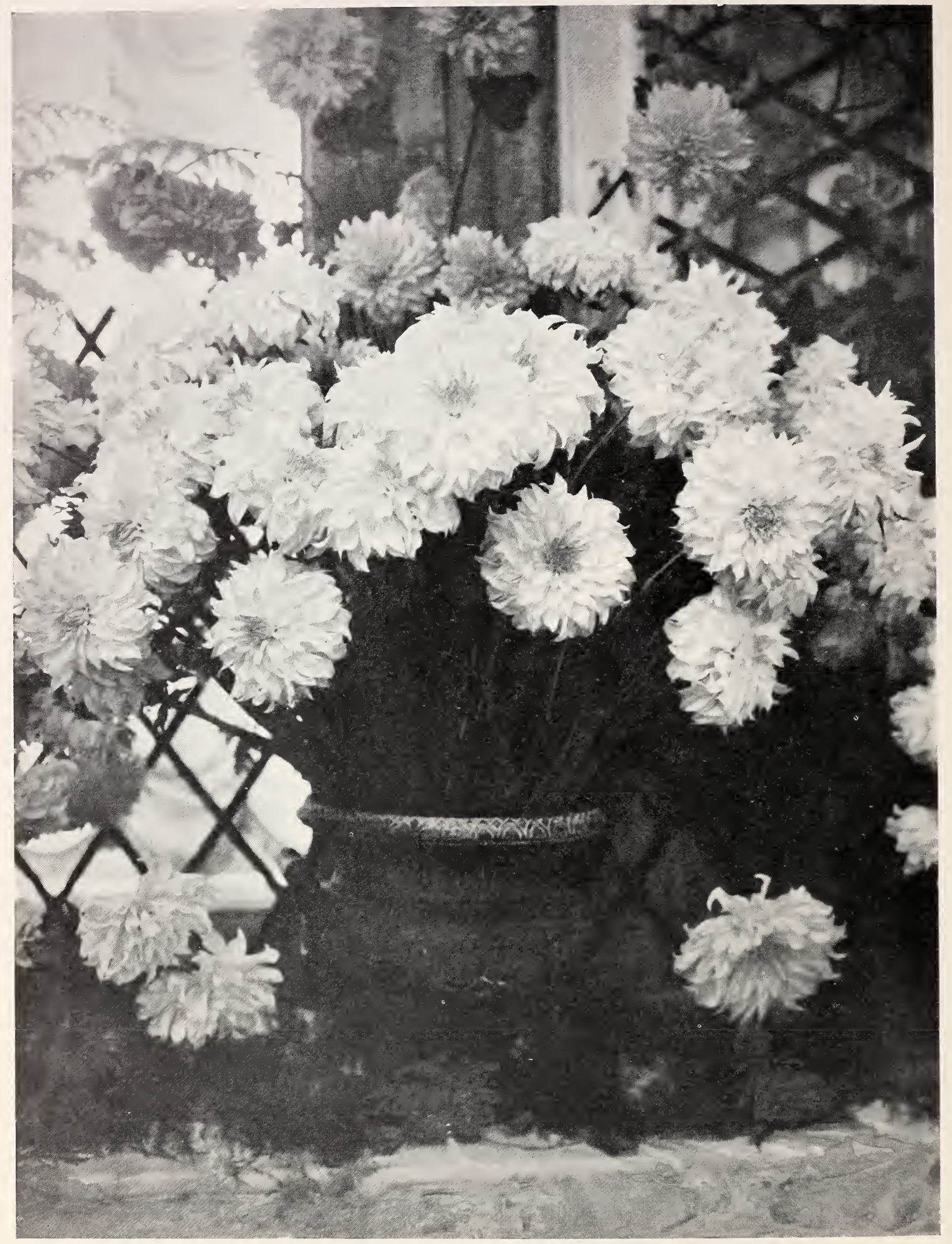

\section{A Vase of Shudow's Lavender}

The exquisite loveliness of these silvery lavender blossoms won the admiration of all; not only adding charm and beauty to our exhibit which won the Gold Medal for Best General Display, but was one of the outstanding features of the entire show. (See page 18 for further description.) 


\section{Hybrid, American, and English Cactus Dahlias}

The hybrid Cactus Dahlias are becoming the most popular. They have broader and more massive petals. Excellent for cut flowers, and being a hardy variety, do well in almost any climate.

American Cactus is a new type. The petals are coarser than the English exhibition, but not heavy enough to form a hybrid. In the East, flowers of this type are still permitted in the Cactus collections.

The English Cactus Dahlias have long, narrow, pointed petals, like a chrysanthemum. They will always be favorites owing to their unique and spidery formation.

ALABASTER-The finest white English Cactus. Large and incurved. An indispensable exhibition variety, beautiful for garden and a fine cut flower. $\$ 1.00$.

$\star$ AMBASSADOR-Hybrid Cactus. One of the most sensational varieties ever originated, and a general favorite. In formation it resembles a huge sunburst. Its color is soft yellow, with salmon, amber and pink shadings, gradually deepening toward the tips of the petals. The flowers are of the largest size, and are held perfectly erect on extra strong stems. Our stock is the prize winning strain and always comes full to the center. Ambassador was included in our twelve best Californians. $\$ 3.00$.

$\star$ AMBER GLOW-English Cactus. A bright yellow, deepening to pale orange at the center. The petals are long, narrow and straight. An exhibition and cut flower variety. $\$ 1.00$.

A. R. PERRY -English Cactus. Old rose, tipped with gold. A very beautiful and large exhibition flower, with long, narrow, incurved petals. The stems are good. $75 \mathrm{c}$.

$\star$ BALLET GIRL-English Cactus. A flower difficult to describe. It is sometimes orange with a white edge, then again, white shading to orange, or white edged orange, and at times pure orange. The immense blooms attract the attention of every visitor to the garden. Of perfect formation and a good cut flower. \$1.50.

$\star$ CALIFORNIA ENCHANTRESS-Hybrid Cactus. An immense bloom of great substance. It is a delightful shade of pale pink. The stem is fine and it is free flowering. This beautiful dahlia has given satisfaction wherever it has been grown. $\$ 1.00$.

$\star$ CLAIRE WINDSOR-An excellent pure white Hybrid Cactus, with all good traits. As a cut flower it is unexcelled, the stems are perfect, long and strong, and the tall bush is continually covered with the large, perfectly formed flowers. Claire Windsor is a valuable acquisition to any garden, and can be used for a background effect as the bush frequently grows six or eight feet tall. $\$ 3.00$.

$\star$ DADDY BUTLER-An immense hybrid cactus of truest form for exhibition, and a good cut-flower. A most unusual blending of colors-American Beauty shades or rosy carmine, and the reverse of the beautifully twisted and rolled petals of a lighter tint, giving a variation of color. The stem is perfect, and the bush is always covered with large, perfect blooms, which last for days when cut. This dahlia was included in our twelve best Californians in 1925 . \$2.00.

$\star$ EL GRANADA-Another Gold Medal Hybrid Cactus dahlia that is a great prize winner. Its color is a vivid orange, and the petals twist and interlace, showing at the tips a creamy yellow reverse. The beautiful flowers grow well out of the foliage on long, fine stems. It is an early bloomer. The bushes are covered with these large, deep flowers which have closed centers, until late in the season. This is one of Bessie Boston's most sensational creations, and was included in our twelre best California Dahlias at the recent show. $\$ 5.00$.

*ELSIE OLIVER-Hybrid Cactus. An enormous creamy pink, shading to cream in the center-a delicate new pastel blend of pink and cream. This beautiful dahlia of perfect formation is a great favorite and admired by all visitors to our gardens. $\$ 2.00$.

$\star$ EMPIRE (American Cactus Type)-The large bold flower is composed of many perfectly rolled, incurved petals. The color is deeper at the center, and gradually lightens to pure raspberry. Always full to the center; perfect stems. \$2.C0.

$\star$ ESTHER HUNT_Hybrid Cactus. Large blooms composed of long, well rolled petals with serrated tips. The vivid colored flower of Oriental orange has an absolutely perfect center, and makes a striking display. Fine long stems. \$2.00.

$\star$ FRANCES WHEELER-(One of our 1927 introductions.) A Hybrid Cactus dahlia that is decidedly out of the ordinary, and almost impossible to describe. The flowers are huge, and of a delightful light creamy yellow, deepening in the center. The reverse of the petals is suffused with a reddish purple and the petals are so fluted or twisted that both colors appear at once. The effect is very novel and charming, as the flower has, as one visitor exclaimed, a "marcelled" effect. The stems are perfect and the tall bushes are continually in bloom, from early till late. We take great pleasure in presenting this novelty. $\$ 7.50$. 


\section{Hybrid, American, and English Cactus Dahlias}

$\star$ FLUFFY RUFFLES-This charming Hybrid Cactus of ours is a beautiful blossom of golden fawn with a satin sheen, shading to a golden yellow at center, having petals which twist and turn, showing an old rose reverse that gives a two-toned effect to the whole flower. This dainty good-sized flower is held erect on fine, stiff stems. $\$ 1.50$.

$\star$ GEE WHIZ_A large, attractive Hybrid Cactus of soft buff, shading to salmon, with perfect long stems. A fine garden and exhibition variety. \$1.00.

$\star$ GEORGE WALTERS-This Silver Medal prize winner is one of the best and most popular Hybrid Cactus dahlias, as it does well everywhere. We have always had great demands for this beautiful variety. An immense bloom of a lovely, pinkish salmon, suffused with gold in the center. A wonderful bloomer with long, stout, stiff stems. $75 \mathrm{c}$.

*GLADYS BATES-An American Cactus. Large blooms, of incurved petals of tan, with a reverse of rose. The oddity of coloring is all that is needed to make this dahlia attractive, but it has every good point as well. \$1.50.

$\star$ GOLDEN WEST-American Cactus of great merit because of its coloring, stem and keeping qualities. The color is uncommon, a striking old gold. This dahlia is used extensively by the florists for decorating purposes, especially table decorations. 50c.

‡GLADYS SHERWOOD-Hybrid Cactus. An immense, cream-white blossom, very deep and full to the center, having long, wide, satiny petals that glisten in the sun. Flowers are held erect on long, stiff stems. A fine garden or exhibition variety. $75 \mathrm{c}$.

$\star$ HELEN DURNBAUGH-An extremely beautiful and dainty Hybrid Cactus of exquisite pink, shading to white. The large blooms are held erect on fine, long, stiff stems. No dahlia has ever given greater satisfaction, due to its loveliness. A good keeper. 50c.

HERBERT RABY-English Cactus. Wine crimson, huge flowers. Long, narrow incurving petals. Another good exhibition cactus. 50c.

HOMER-The darkest of all the English Cactus, being almost black. Incurved, with good stems. $75 \mathrm{c}$.

JEAN CHAZOT, or GAY PAREE-A French dahlia of delightful autumn coloring of golden bronze suffused with nasturtium red. Large flower with long, strong stem, especially fine for cutting. American type. $\$ \mathbf{1 . 0 0}$.

KALIF-Its brilliant pure scarlet color, strong, stout stems, large perfect formation make it one of our most useful Hybrid cactus dahlias. 75c.

$\star$ KOHINOOR-One of the finest of dark red Hybrid Cactus dahlias. Immense blossoms of maroon, and at times so dark as to be nearly black. These huge flowers of perfect type, large and deep, are held by stems stiff as a cane. Kohinoor is always invaluable for the dark effect in an Autumn basket. $\$ 2.50$.

$\star$ LA FAVORITA - A beautiful blossom of a new and distinctive coloring. Large flower of a most brilliant Oriental orange, always full to the center, and carried on a long, strong stem. Perfect formation for Hybrid Cactus competition. In great demand as a cut flower, as it tones so well with the sunset and Autumn-hued dahlias, with its rich Oriental coloring, and artistically twisted petals. 75c.

MacGREGOR-Hybrid Cactus. This is one of the "Mastick" dahlias. A lovely nopal or soft red, with the base of the petals lemon yellow. These beautiful flowers are large and full and carried on long and upright stems and keep well when cut. \$2.50.

* MARIPOSA-There has never been a greater favorite than this delightful shaggy lavender pink hybrid cactus. The beautiful pink coloring is intensified by a violet suffusion, which deepens at the center. This immense perfectly formed blossom has depth as well as diameter, and stands absolutely erect on a firm, stiff stem which rises at least three feet out of the foliage. Is an early bloomer and keeps its center throughout the season. No dahlia has ever won more prizes. Mariposa again helped us win in the twelve best Californians this year, making three consecutive seasons this variety has been included in this entry. \$2.50. 


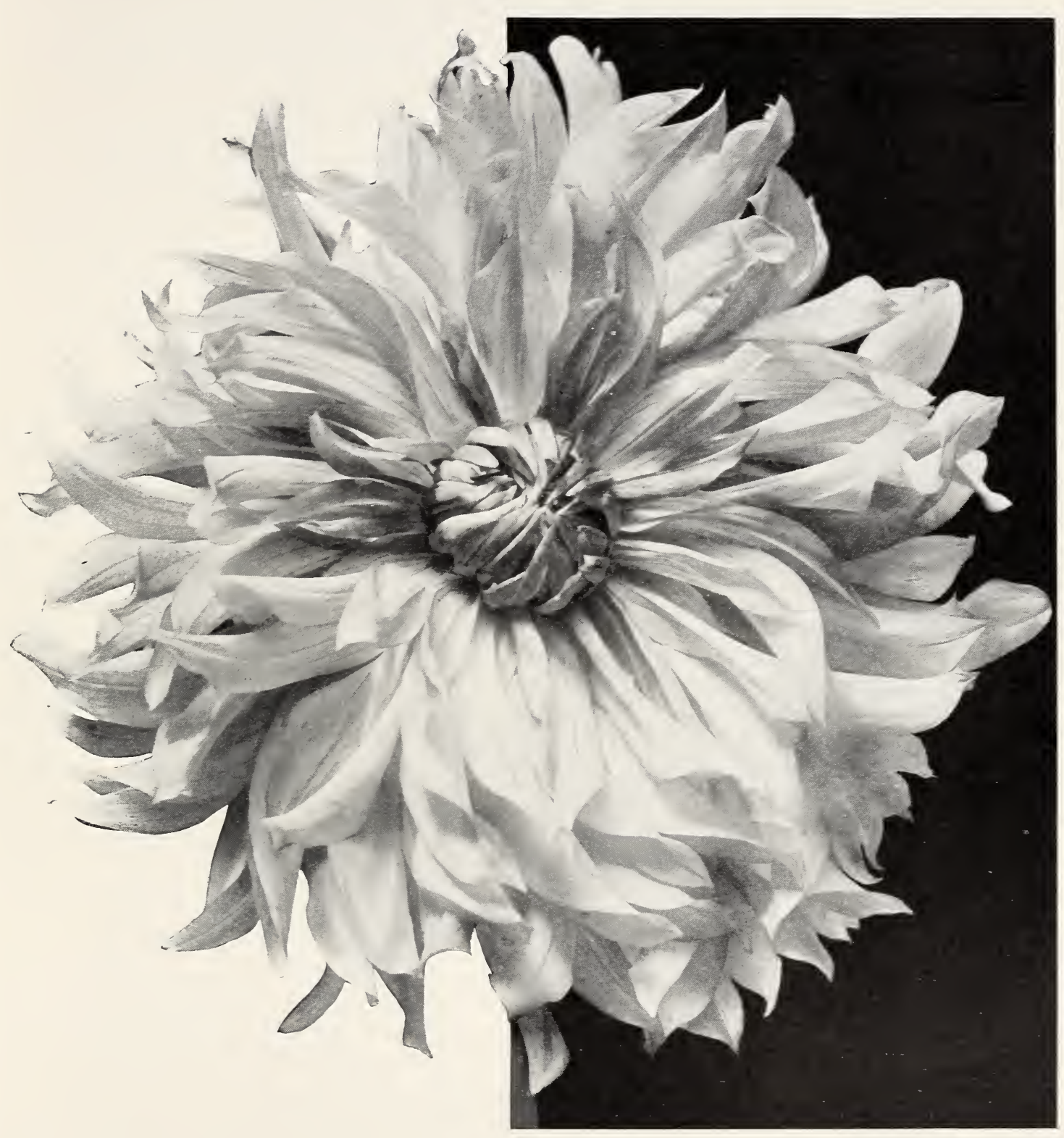

\section{Hybrid Cactus Dahlia-Mariposa}

This beautiful dahlia is of a delightful shade of pink which is intensified by a deeper colored center. A faint violet suffusion adds greatly to the charm of the dahlia. At the 1923 Exhibition of The American Dahlia Society, held in New York, this wonderful dahlia headed the list of the fourteen varieties selected as the most popular prize winners. Mariposa was also a prize winner at our recent exhibition at the Palace Hotel. (For further description see opposite page.) 


\section{Hybrid, American, and English Cactus Dahlias}

*MINAMOTO-A bright velvety scarlet blossom of enormous size and fine depth. Stem is long and stiff and the flower keeps its center throughout the entire season. Hybrid Cactus. \$1.00.

MRS. ALFRED HARVEY-A large, fine English Cactus, with incurved florets gracefully arranged, and a beautiful color; light salmon pink, with darker shadings toward the center. Perfect flowers on good stems. $\$ 2.00$.

$\star$ MRS. EDNA SPENCER-This American Cactus is a novelty of a delicate and exquisite shade of lavender or orchid pink. In much demand, as it is a lasting cut flower of unusual color and very beautiful under artificial light. The florists prefer this to any other cactus dahlia, and it is always a prize winner in American cactus competition. The stems are long and stiff. 50c.

*MRS. W. E. ESTES-This incomparable white Hybrid Cactus dahlia is one of the largest and best snow whites grown. Does well in a warm climate as it never burns in the sunshine. The immense bloom, with its petals deep and full, is held high above the foliage on a long, strong stem, making a most excellent cut flower. $\$ 1.00$.

(See illustration on opposite page)

$\star$ NICHU-An extremely large light sulphur yellow Hybrid Cactus of perfect formation. The flowers have fine, long, stiff stems and remarkable keeping qualities, lasting for days when cut. $\$ \mathbf{\$ 5 . 0 0}$.

$\star$ OBERON-Deep old rose with the most pronounced violet suffusion; an exceedingly rich and attractive combination. The deep flowers of perfect Hybrid Cactus type, have long, strong upright stems, and remain double the entire season. $\$ \mathbf{2 . 0 0}$.

^PARADISE-A bold, massive Hybrid Cactus of decidedly different coloring-creamy old rose suffused with gold, so blended to give it a striking brown tone. This is a free blooming dahlia with extra long stiff stems. $\$ \mathbf{2 . 0 0}$.

PIERROT-Lovely deep amber, usually boldly tipped with white. Immense flowers, if disbudded are huge. Sensational exhibition English Cactus. 50c.

ÆREGENT-American Cactus type. A clear mauve pink. The many petals are scarcely coarser than the English type. This very beautiful dahlia is also a winner in American Cactus competition. The stems are extra long and stiff. $\$ 1.00$.

$\star$ ROLLO BOY-Another Hybrid Cactus that is a dandy, and can be grown to immense size. Every flower is carried perfectly erect on a long, stiff stem. The color is a delicate shade of amber, deepening to old gold. Rollo Boy is a very conspicuous garden plant, and if desired for exhibition is in the "largest dahlia" class. This fine variety helped to win the "Best Collection of California Dahlias" for us this past year. $\$ 3.00$.

ROSA BONHEUR-Hybrid Cactus. A graceful combination of dainty form and clear color. Ivory white center, shading to a beautiful shell pink. The outer petals prettily twisted and curled give a graceful appearance. A free bloomer with good stem. $\$ 3.50$.

$\star$ SILVERADO-(One of our 1927 introductions.) Our Napa farm is located in the heart of the Silverado country immortalized by Robert Louis Stevenson; in fact, an hour's ride takes one to the exact spot, on historic Mt. St. Helena, where the author first visualized his "Silverado Squatters". Naturally it has been our ambition to originate a dahlia worthy of this name, and after many disappointments we finally succeeded beyond our greatest expectations, and so take great pleasure in introducing our new Silverado, without doubt the largest dahlia of its class ever produced. The immense blooms are of white, gradually shading toward the center to a delicate silvery lavender. The stems are extra long and strong, and the tall, well branched bushes are always covered with these huge, feathery blooms. We have over a hundred plants of Silverado in our display garden, and everyone was captivated by their beauty. $\$ 10.00$.

(See illustration on page 4)

SILVERHILL PARK-A beautiful new white English Cactus. Large in size, beautifully incurved in form and with a perfect center. Strong plants and good stems. $\$ 1.00$. 


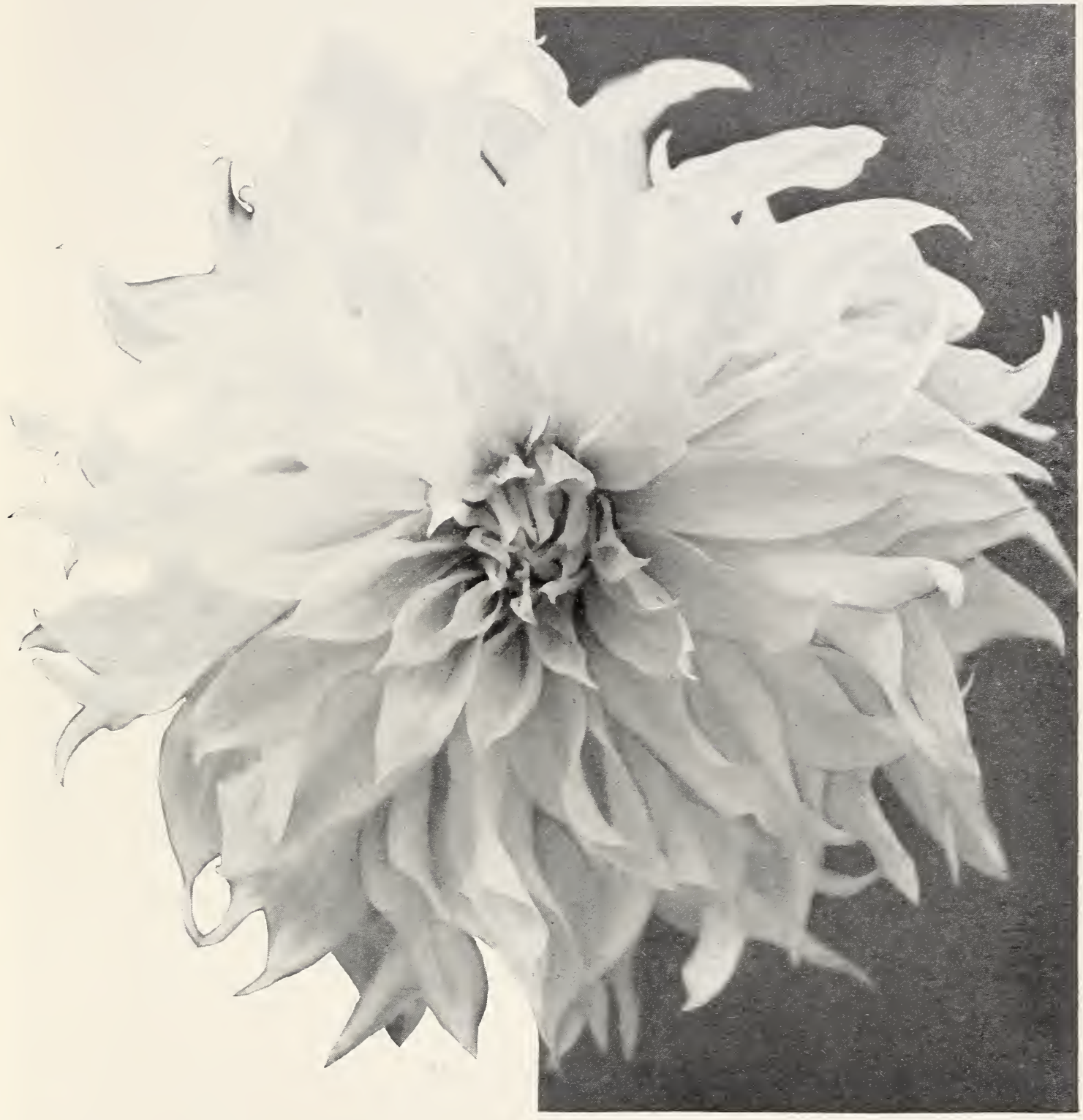

\section{Hybrid Cactus Dahlia-Mrs. W. E. Estes}

An incomparable snow white Dahlia, of a most artistic formation, with a long, strong stem. For exhibition and cut flower purposes, this variety is unexcelled. (For further description see opposite page.) 


\section{Hybrid, American, and English Cactus Dahlias}

SOVEREIGNTY - Very large flowers of deep yellow; almost straight petals. Fine for exhibiting. English Cactus. \$1.00.

$\star$ SUNMAID_(Novelty Hybrid Cactus.) A very gorgeous blending of orange and gold. The flowers are huge, of the "Insulinde" formation, of great depth, and are borne on extra strong stems. This Prize Winning dahlia was much admired in our garden the past season. $\$ 7.50$.

$\star$ THE EAGLE-Hybrid Cactus. A large flower of sulphur yellow, with long, stiff stems. This dahlia does exceptionally well in a warm climate. Fine for exhibiting as well as for cutting. 75c.

$\star$ TOM LUNDY-The rich, dark, velvety, crimson flowers are immense in size and have good stems. This Hybrid Cactus dahlia does exceptionally well in a warm climate and gives great pleasure to the grower. $\mathbf{7 5 c}$.

UNION JACK-A striking novelty. Large red incurved petals, tipped white. A very attractive English Cactus dahlia, greatly admired in the garden and on the exhibiiton table. 50c.

$\star$ ZANTE-A fine new Hybrid Cactus with every good feature. A large, perfect flower of gold, heavily suffused with pink, with a deeper shading toward the center. The blooms are perfect the entire Season, and never show an open center. The stems are extra long and stiff and hold the blooms proudly erect. Zante can be highly recommended for all purposes. $\$ \mathbf{5 5 . 0 0}$.

Dahlias marked $\star$ originated in California.

\section{Peony or Art Dahlias}



The peony dahlias "Gorgeous", "Elizabeth Boston" and "The Oriole"-a glorious combination of sunset and Autumn coloring-were used in the above peony basket, winning for us the First Prize in 1925 and 1926. 


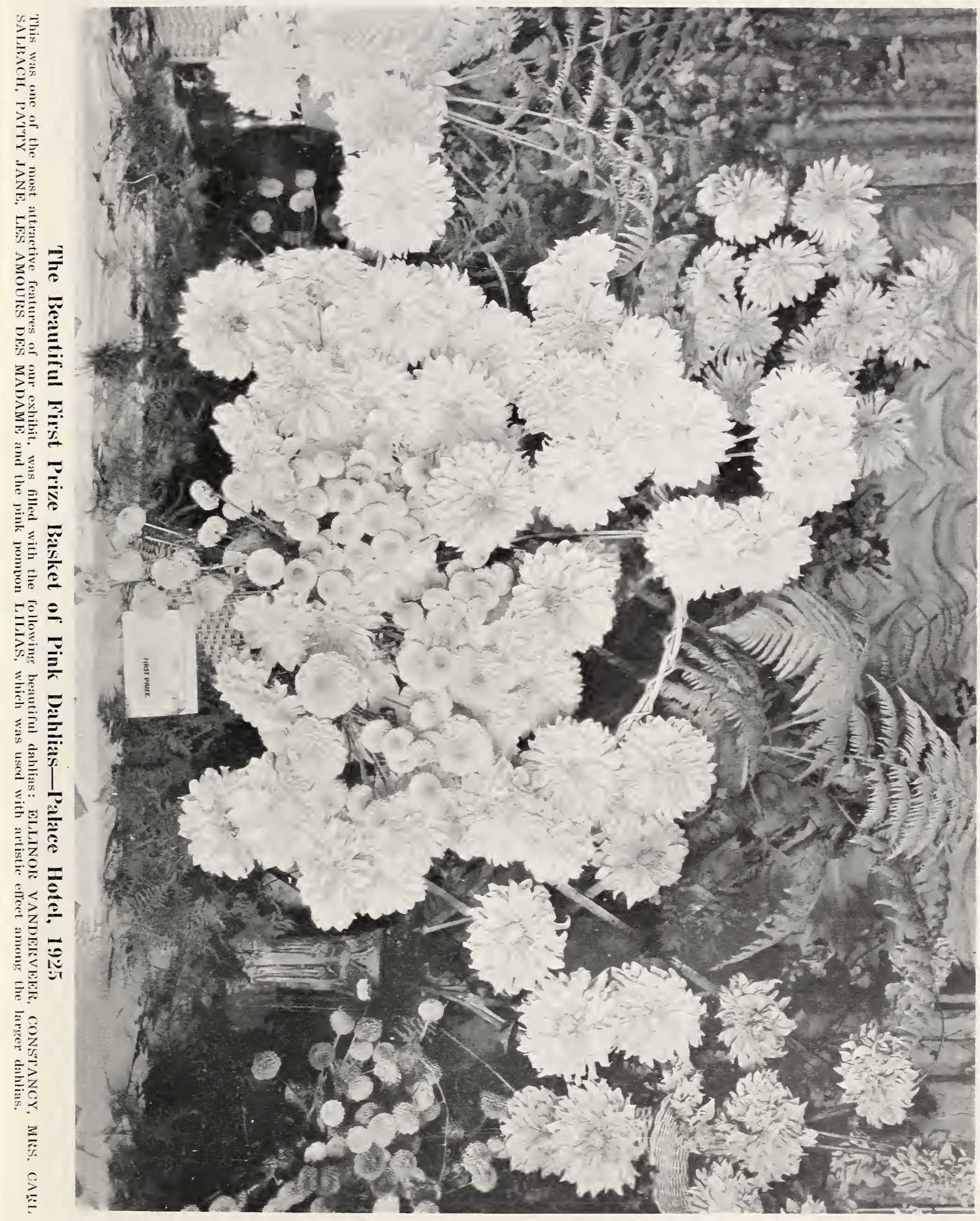




\section{Peony or Art Dahlias}

The Peony or Art Dahlias are of recent introduction, and are extremely popular. Flowers are large, Having two to five rows of petals, very broad, and artistically twisted and curled. They usually show the golden center, and have small curling petals clustered around it. They are free flowering, and their long, straight stems make them a beautiful growing and cutting variety.

ALBERT WARD-An immense flower of deep purple, and one of the best peonies ever introduced. A perfect exhibition flower which stands erect on a long, stiff stem. This beautiful flower attracted great attention in our garden as true purple is rare. The formation of this dahlia is perfect and should be in every garden. $\$ 1.00$.

$\star$ BLOSSOM-Immense flowers of white with a faint pink at the base of the petals, suggesting the dainty colorings seen in the fruit blossoms. A perfect exhibition flower; blooms held high above bush on long, stiff stems and last for days when cut. $\$ 1.00$.

$\star$ BLUE BIRD-An exceptional color of the deepest tone of mauve or lilac which in certain lights has a bluish sheen. Large blossoms, held erect on long, stiff stems. $\$ 1.00$.

CARDINAL MERCIER-Supreme in its coloring, being a deep flesh pink with light veins of canary shooting up from the base of the petals in the center. Then there appears a glistening silvery sheen of the white-flesh peach. The curly formation of the florets of this beautiful flower is indeed remarkable. \$2.00.

$\star \mathrm{CHANSON}$-The color of this large, heavy Peony is an entirely new one-deepest lilac with a bluish sheen. Petals are numerous and it has a strong, erect stem, excellent for exhibiting and cutting. \$1.00.

CITY OF PORTLAND-One of the best ever introduced. Color a clear, deep, rich yellow. It has every good quality; immense flowers that are graceful and artistic, held upright on long, strong stems that show them to full view; the plants are strong and vigorous and produce their flowers with unusual freedom. 75c.

$\star$ COPPER-Copper-colored blossoms, shaded and tinted with bronze and apricot. This blossom is held high above the foliage on a strong, stiff stem. 75c.

CREAM KING-An immense flower on long, strong stems. A deep cream. Indispensable for garden and exhibition purposes. 75c.

^DREAMLIGHT-A most enchanting b'ossom of a lovely shade of old rose pink, deepening to a golden yellow at base. The flowers are large and the bush is always covered with a mass of these most beautiful blooms. We had a long row of Dreamlight in our garden and it was surely a wonderful display the entire season. The stems are perfect and hold the flowers erect. $\$ 2.00$.

$\star$ EL PAJARO (In Spanish "The Bird")—One of our 1926 introductions, originated by G. W. Silvair. There is no better way of describing this beautiful dahlia than calling it an art dahlia. It comes in decorative form the first of the season, but a little later it is of a peony formation. The petals are extremely full and twirl and twist in a most artistic manner, and have many charming little florets in the center. It is a large size dahlia, pink being its predominating color-the beautiful rose pink outlining the outer edges and throughout the center of the petals. The base of the petals is a bright golden yellow which is also slightly suffused through the flower. These beautiful blossoms, held high and erect over a fine sturdy bush on long, stiff stems, attracted much attention in our gardens this year. \$2.50.

^ELEANOR HERRICK-A marvelously large, light maroon Peony, with a long, straight stem. This dahlia is of perfect form for exhibiting and keeps its size all season. $\$ 1.00$.

^GORGEOUS-Rightly named, yellow shading to bright scarlet. These gorgeous blossoms of tremendous size and great depth, stand erect on exceedingly long, stiff stems, and add striking beauty to the garden. Because of their unusual substance the blossoms are splendid exhibition and cut flowers. The plant grows very tall and late blooms will be as large as the early ones. This is one of the finest Peony dahlias we have ever grown and one of the most useful. \$1.50.

$\star$ MRS. C. E. TROWER-This lovely dahlia of ours, which I have named for my sister. is a salmon rose pink, shading to a lighter pink at the tips of the petals, and to a bright golden yellow at base. Many tiny florets cluster around the golden disc, making it a very artistic blossom. It has exceptionally long, strong, stiff stems which hold the unusually striking flowers very erect. $\$ 1.00$. 


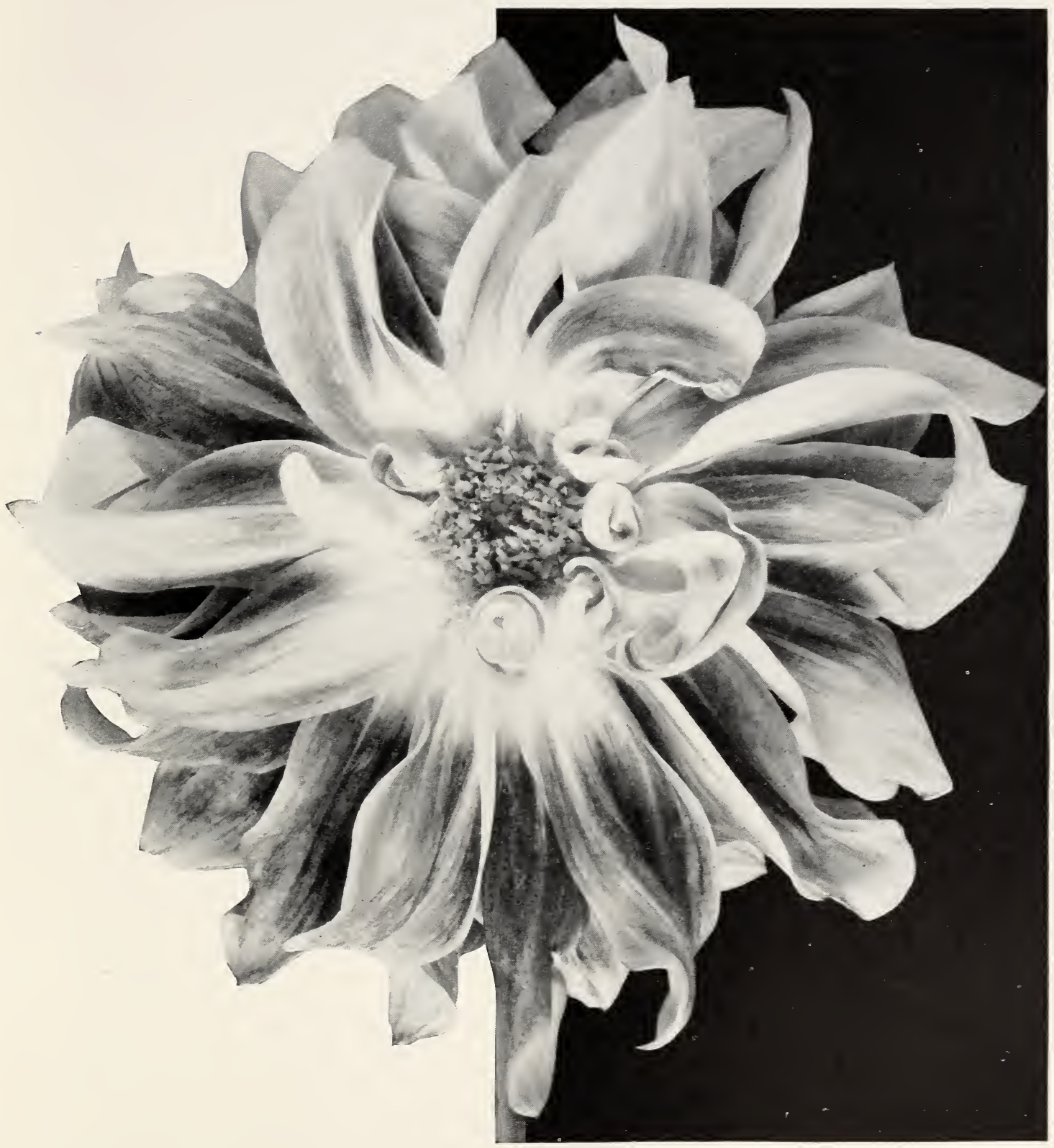

\section{Peony Dahlia-Pearl Ruggles}

One of the largest and most exquisitely colored Peony Dahlias. A carmine rose suffused with pink shading lighter at tips, and to white at base of petals. The beautiful blossom is held erect on an extra long, fine stem. (For further description see page 30.) 


\section{Peony or Art Dahlias}

MRS. JIII McCANDLESS-A fine large peony of old gold shading to apricot. The very beautiful flowers are held on good stems, and the bush is always covered with bloom. Mrs. Jim McCandless is very useful for exhibition and cut flower purposes, and is always used in our Autumn baskets. \$2.00.

*NATALIE MAI-A huge, deep rich burgundy blossom with maroon shadings, lightening to cream at the edge. Many artistic florets surround the center, giving a most artistic effect. $75 \mathrm{c}$.

^PEARL RUGGLES-One of the largest and most exquisitely colored. A carmine rose suffused with pink shading lighter at tips, and to white at the base of petals. Extra long, fine stems hold this beautiful blossom erect. The long petals twist and curl, and the yellow disc is surrounded with lovely little florets, giving the whole a very artistic effect. We have never introduced a dahlia which has given greater satisfaction. $\$ \mathbf{1 1 . 0 0}$.

THE BILLIONAIRE-A favorite that continues to hold its popularity. The huge flowers among the largest of the Peony type, are of a wonderful shade of deep gold with a suggestion of orange. The tall bushes are always covered with these most attractive blooms, which, for baskets, or home decoration, cannot be surpassed. $\$ 1.00$.

$\star$ THE ORIOLE-Perhaps the most striking Peony in our garden, as it is a very remarkable combination of burnt orange, red and yellow. Many of the flowers shade to white at the tips. These showy blossoms, with their gorgeous Autumn colorings, are very large and are held erect on fine, long, stiff stems. The Oriole is also a very prolific bloomer. $\$ 1.00$.

UNCLE SAM-An Eastern dahlia that surely is a dandy. The color of this huge variety is orange buff, shading to pink, and the whole flower has a glistening effect in the sunshine. The beautiful, deep blossoms stand erect on long, strong stems, proudly held above the bush. Uncle Sam is a prize winner, having taken many prizes in the East as the largest dahlia in the show. $\$ \mathbf{1 . 5 0}$.

$\star$ VIV A NDIERE-An immense deep Peony, of cerise carmine, shading lighter at the tips of the petals. The flower has a peculiar velvety texture. The stems of this early bloomer are excellent. $\$ 1.00$.

\section{Hybrid Show Dahlias}

The Hybrid or Giant Shows are becoming great favorites on account of their tremendous size. They are not as tightly quilled, but are looser petaled and not as stiff as the Show Dahlias. They are very attractive.

$\star$ ANNA REHORST-Large flowers of deepest shade of purple. 50c.

BERTHA BERNSTEIN - A fine, large flower. Petals beautifully quilled. Dark lavender in color. These lovely blossoms are almost blue under artificial light. 50c.

$\star$ BETTY BIRD-One of the most beloved dahlias in our garden, of a rich, glowing, rose pink, deepening in the center-one of the most charming of all colors. There is a suggestion of yellow at the base of the petals. The flowers are huge, of a perfect Hybrid show type without the stiffness of the show dahlia and keep unusually well when cut. One could not wish for a more beautiful garden effect than seeing the low growing plants laden with these huge pink balls, held high on long, graceful stems. We have never been able to grow enough stock of this Gold Medal dahlia, and have twice had to withdraw it from market to increase our stock. Stock limited. $\$ 5.00$.

$\star$ CLARA SEATON-Hybrid Show-An enormous flower of rich golden bronze or apricot in color. The flowers are he'd proudly erect, on long, stiff stems. A most attractive garden as well as cut flower. $75 \mathrm{c}$.

‡GOLDEN OPPORTUNITY-Rich Buttercup yellow, shaded burnt oranģe directly in the center of each b!oom. \$1.00.

MAGENTA KING-An immense Hybrid Show of deep magenta. 50c.

MME. MARIE AGNASTOKI-Large pale pink. 50c.

YUBAN-Yellow, striped and speckled red. Immense blooms. 75c.

\section{Show Dahlias}

These are the old-fashioned quilled double flowers and are beloved by many because of their lovely colorings and excellence for cutting.

FLO TRANTER-Bluish white, edged rosy purple. Fine form. 50c.

$\star$ GENERAL HAIG-Best scarlet show. Pure English exhibition type. The large blooms are beautifully quilled. A fine new show. \$1.00.

GLOIRE DE LYON-Very large flower, good for cutting. Fine white. 50c.

GOLD MEDAL-Fancy, bright yel'ow, regularly striped dark crimson. A most popular flower of the brightest Autumn colorings. 75c.

LES AMOURS DES MADAME-Large flower of pink with a stripe of a deeper color. 50c.

TOM JONES-A very beautiful shade of cream, tipped pink. The stems are good and the form is perfect. $\$ 1.00$.

Dahlias marked $\star$ originated in California. 


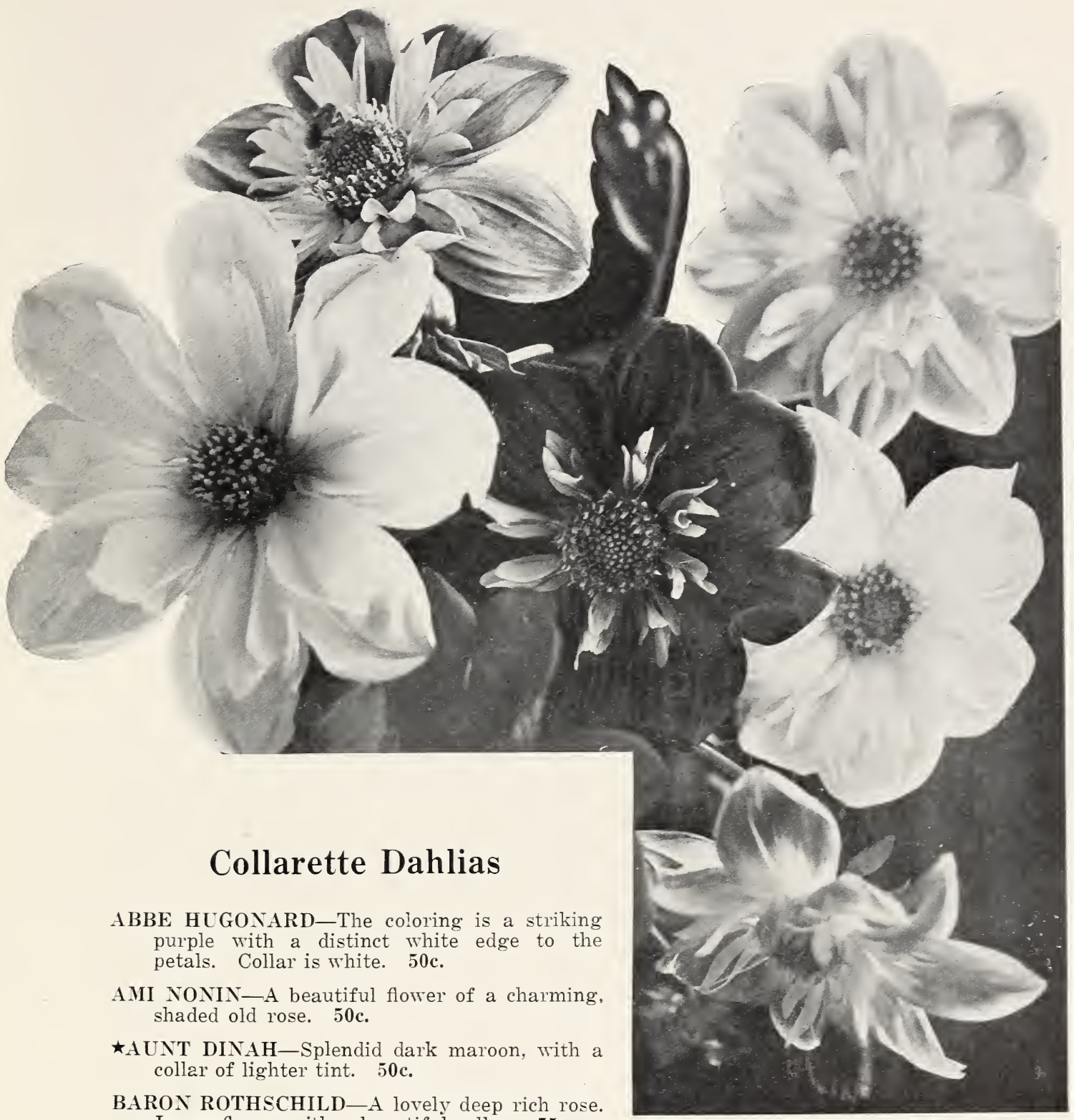
Large flower with a beautiful collar. $75 \mathrm{c}$.

DIOMEDE-Deep carmine, purple-suffused, and edged white, lighter collar; large, very tall and fine. $50 \mathrm{c}$.

^FRANK HARRIS-A very large Collarette with long, straight stems. A distinctive coloring of reddish brown. A free bloomer. $\$ 1.00$.

GEANT DE LYON-An enormous flower of velvety maroon, with a long, white collar. One of the largest, $\$ 1.00$.

HERALD-Large, rich, rosy pink with white collar. Very beautiful and indispensable for cutting and exhibitions. 50c.

$\star$ MON AMI-A flaming scarlet blossom lightly tipped with gold. The collar is yellow with a gradual shading of vermilion. $50 \mathrm{c}$.

$\star$ RAFAEL VELASCO-A very dark purple Collarette, with a pure white collar. 75̣c. Dahlias marked $\star$ originated in California. 


\section{Collarette Dahlias}

$\star$ SAN MATEO STAR-The largest Collarette. Cerise, the petals edged white, and the collar white. $\$ 1.00$.

$\star$ SILVER MEDAL-Large beautiful crimson-maroon with each petal distinctly outlined in white, with a white collar in contrast. 50c.

SOUV. BEL ACCUEIL-This orange-red, with a yellow collar, is one of the largest as well as one of the most beautiful. 50c.

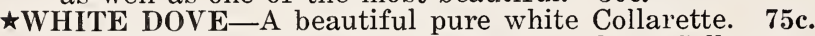

$\star W M$. WELSH-One of the largest and best Collarettes. A creamy yellow with a long collar of same color. 50c.

Dahlias marked $\star$ originated in California.

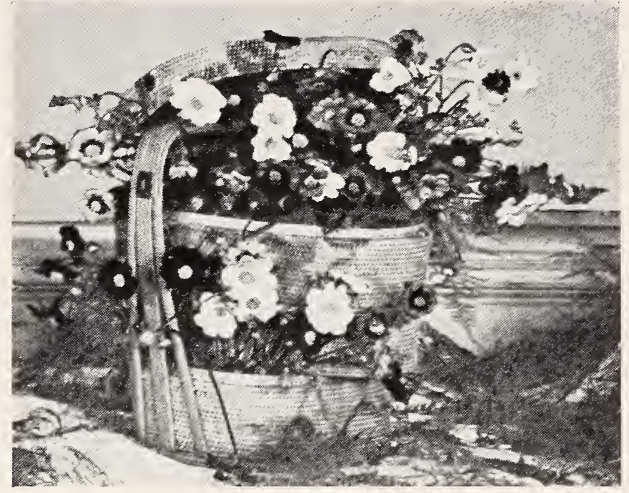

European Single Dahlias

These miniature Dahlias are indescribably beautiful, and have remarkable color combinations. Our basket of these delightful Single Dahlias was awarded First Prize at the recent Palace Hotel Show.

BETTY-Lovely shade of rosy lilac with dark crimson ring around center. 75c.

ETOILE DE FOCH (French Novelty) - A new departure in the Dahlia world. A single, with petals rolled in such a way as to form a perfect star. Clear yellow, with moired carmine reverse, and the reverse is as prominent as the face of the petal, being always rolled forward, making the dahlia two toned. Very attractive. 50c. FUGI SAN-Bronze yellow flowers with crimson ring. $75 \mathrm{c}$.

MRS. JOYSON HICKS-Rich, bronzy tan, with crimson ring. Very beautiful. 75c. PRINCESS OF WALES-Soft pink, very pretty and dainty. 75c.

SAMBO-Intense dark crimson. Very velvety. One of the choicest. 75c.

STROMBOLI-Dark maroon, tipped white. Sometimes the blossoms are of solid color. $75 \mathrm{c}$.

SNOWDROP-White; the beautiful, smooth flowers borne erect on wiry stems. 75c.

UNION JACK SINGLE_-White, striped with red. Very unique and striking when clumped together or used as borders. This little gem always attracts attention. $75 \mathrm{c}$.

\section{Dahlia Collections}

We are offering this season SPECIAL COLLECTIONS made up of one tuber each of our most popular varieties. This gives an opportunity of securing a choice collection at a greatly reduced cost. These collections are carefully balanced as to color, and are made up of large dahlias only. There are twelve guaranteed tubers in each collection, all labeled and of varieties that can be found in this catalog. WE PREPAY ALL POSTAGE. These collections- $\$ 5.00, \$ 10.00, \$ 15.00$ and $\$ 25.00$.

\section{The Sies Dahlia Manual}

We are the distributors of the Sies Dahlia Manual, which covers all points for the successful raising of Dahlias to perfection. This is a most thorough, comprehensive, and practical study of the Dahlia and worth many times the amount asked. 60c. 


\section{Pompon Dahlias}

Pompons are the gems of the dahlia family, producing very small, compact flowers like diminutive show dahlias; they are invaluable for cut flowers owing to their good keeping qualities.

We won the First Prize for the Best Collection of Pompons at the 192.5 and 1926 Dahita shous of the Dahlia Society of California.

Our Pompons have uon many First Prizes for our customers throughout the country.

*AIMEE-Tiny bronze flowers with long stems. 50c.

AMBER QUEEN-Deep amber-good for cutting. 35̃c.

$\star$ ANITA-New, old rose, small and free flowering. 75c.

$\star$ ARTHUR-New-brilliant scarlet. Small and well formed. $\$ 1.00$.

BACCHUS-An excellent bright scarlet for cutting. 35̌c.

$\star$ CLEO-Yellow, tipped lightly with red; small. 50c.

CYRIL-Deep, rich red, of perfect form. Fine for cutting. 50c.

DAISY_Perfect flower of light, pinkish amber. Blends well with Glow. 50c.

$\star$ DEEDEE-A perfectly formed pure lavender. Dainty and small. 50c.

$\star$ ELIZABETH-Golden yellow edged with brownish red; long stems. 50c.

EUNICE-White, with a lavender edge; good for cutting. 50c.

$\star$ GENE-New-light gold with brown eyed center. Fine cut flower. 75c.

GIRLIE-Lilac pink. Very popular. Excellent for cutting. 50c.

GLOW-Pure old rose-perfect form. One of the most popular. 50c.

$\star$ GOLDIE-A tiny flower of pure gold, fine for cutting. 75c.

HARRY SNOOK-A small, perfect flower of most delicate pink, shading to white at tips. $50 \mathrm{c}$.

$\star$ HAZEL-New. A buff deepening to brown. Small, fine form. $75 \mathrm{c}$.

$\star$ JOE FETTE-An exceedingly fine white for all purposes. $50 \mathrm{c}$.

JOHNNY-Very dark red; one of the smallest and most perfect. 50c.

$\star$ KIMI-Bright orange and a good cut flower. $50 \mathrm{c}$.

LASSIE-Yellow base, old rose shadings. $50 \mathrm{c}$.

LILIAS OR LILAC-One of the loveliest pompons. Cream ground heavily suffused with pink with a lilac sheen. Very beautiful. $50 \mathrm{c}$.

LITTLE BEESWING-Golden yellow, tipped cherry; small; fine form. 50c.

$\star$ LITTLE BUGLER-Rosy purple; long stems. $50 \mathrm{c}$.

$\star$ LITTLE DAVID (New)-The deepest shade of orange. Small, perfectly shaped, free blooming, and one of the best for cutting and exhibiting. $75 \mathrm{c}$.

LITTLE DONALD-Dark crimson; small and good form. 50c.

MARIETTA-Deep rosy crimson, fine for cutting. 50c.

* MIKE-A charming new color of burnt orange, shading lighter at the outer petals. Flower is small and perfect. A free bloomer. $\$ 1.00$.

NELLIE BROOMHEAD-A gold base, heavily suffused rose pink. 50c.

NELLIE FRASER-Light ground, edged and tipped with rose. $50 \mathrm{c}$.

NERISSA-True pink; very dainty and rare. 50c.

$\star$ OLETA-Soft Oriental red, with extra long, stiff stems. $\$ 1.00$.

PERFECT-Yellow, decidedly tipped with rosy pink. Most attractive. 75c.

PHYLLIS-Deep yellow, shaded and edged red; good form. Very small. 50c.

$\star$ RALPH-A light red pompon that is fine for cutting. New, perfect formation. \$1.00.

REGULUS (Little Dorritt)-Beautiful cerise purple, small, perfect formation. 50c.

ROSEBUD (Blush Gem)—White ground, edged rosy pink. Fine for cutting. 50c.

SUNSET-A delightful orange, one of the most popular. 35c.

$\star$ TOM-Small and compact flower of bright yellow, tipped sunset red. Free flowering: and fine in Autumn bouquets. $75 \mathrm{c}$.

TOMMY KEITH-A small, perfectly formed blossom of deep red, tipped white. Very attractive. $50 \mathrm{c}$.

$\star$ TOM THUMB-Garnet red. A winner in the smallest flower class. 50c.

$\star$ YELLOW GEM-Creamy yellow, small and fine form. 50c.

Dahlias marked $\star$ originated in California.

One dozen pompons listed, our selection, for $\$ 4.50$ 




A view of our exhibit which won First Prize "For Best General Display" at the Ninth Annual Exhibition of the Dahlia Society of California, held at the Palace Hotel, 1924. The manner in which we displayed our Pompons was very effective. 



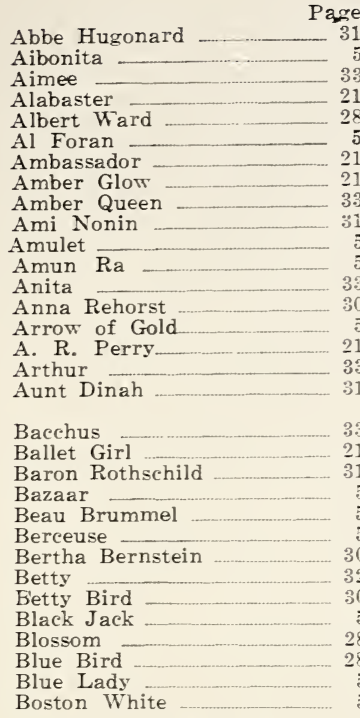

California Enchantress …_... 2 Cardinal Mercier __... 2

Champagne

Chanson

Cho

City of Portland

Claire Windsor

Clara Seaton

Cleo

Copper

Conchita

Constancy

Cream King $\quad 28$

Cyril $\quad 33$

Daddy Butler

Daisy

Diomede

Dixie

Dreamlight

Dr. Tevis

Earle Williams

*Eileen Roxborough

El Dorado

El Granada ㄴ 21

Eleanor Herrick _ 28

Ellinor Vanderveer

El Pajaro

Elsie Oliver

Elizabeth

Empire

Esther Hunt

Evelyn Adamson

Faith Garibaldi

Flo Tranter

Fluffy Ruffles

Frances Wheeler

Frank Harris _

Fugi San _

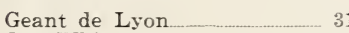

Gee Whiz.

George Walters ______ 22

Gene …..........................

General Haig ______ 30

Girlie __. 33

Gladys Bates — 22

$\begin{array}{ll}* \text { Gladys Rolands } & 10 \\ \text { Gladys Sherwood } & 22\end{array}$

$\begin{array}{lrlr}\text { Gloire de Lyon } & \text { Page } & \text { Page } \\ \text { Gloriana } & 30 & \text { Paradise } & 21 \\ \text { Glow } & 10 & \text { Patty Jane } & 30 \\ \text { Golden Medal } & 33 & \text { Pearl Ruggles } & 16 \\ \text { Golden Fleece } & 30 & \text { Peerless } & 33 \\ \text { Golden Opportunity } & 10 & \text { Perfect } & 24 \\ \text { Golden West } & 30 & \text { Phyllis } & 16 \\ \text { Goldie } & 22 & \text { Pierrot } & 32 \\ \text { Gordon Blanding } & 33 & \text { Pioneer } & 16 \\ \text { Gorgeous } & 10 & \text { Pride of California } & 16 \\ \text { Grenadier } & 28 & \text { Princess of Wales } & \\ \text { Halvella } & 10 & \text { Princess Pat } & \text { Proxie }\end{array}$

Halvella

Harry Davidson

Harry Snook

Hathor

Hazel

Helen Durnbaugh

Herald

Herbert Raby

Homer

Jersey's B'eauty

Jean Chazot

Jessie K. Prescott

Joe Fette

John Alden

Johnny

Judge Marean

Junior

J. W. Davies.

John Doe of $\mathrm{Oz}$

Kalif

King Tut

Kittie Dunlap

Klamath Beauty

Kohinoor

Lady Betty

La Favorita

Lassie

Leah M. Gleadell

Les Amours Des Madame

Lilias

Little Beeswing

Little David

Little Donald

Logan's White

MacGregor

Magenta King

Marietta

Mariposa

Marjorie Hennessey

Marmion

Meadow Lark

Mephistopheles

M. H. De Young

Mike

Millionaire

Minamoto

Miss California _ 14

Mme. Marie Agnostaki 30

Mon Ami

Mrs. A. Harvey

Mrs. Carl Salbach

Mrs. C. E. Trower

Mrs. Charles Chase

Mrs. E. C. Boston

Mrs. Edna Spencer

Mrs. E. F. T. Smith

Mrs. I. de Ver Warner

Mrs. Jim MeCandless.

Mrs. Joynson Hicks

Mrs. W. E. Estes

Muriel

Natalie Mai

Nellie Broomhead

Nellie Fraser

Nerissa

Nichu

Nobilis

Oasis

Oberon

Olive Reed

Oleta …… 33
Rafael Velasco _____..._. 31

Ralph _._._.................. $3:$

Realization _ _......... 16

Regent _._..... 24

Regulus _ _ _...... 33

Robert Treat ___ 16

Rookwood 16

Rory O'Moore ㄴ..16 16

Rosa Bonheur ㄴ... 24

Rose Fallon ㄴ... 1

Rosa Nell _._____._. 16

Rosebud … 3

Sagamore _.... 16

Salbach's White 18

Sambo $\quad 32$

Scottish Chief _.

Serpolette 18

Shirley Oliver _____ 18

Shower of Gold _ is

Shudow's Lavender ﹎...... 18

Silverado Hill Park $\quad 21$

Siskivou

Snowdrop

Sole Mio 18

Souv Be Accueil $\quad 32$

Sovereignty _ 26

St. Bernard —

St. Francis

Stromboli

Suffragette

Sultan.

Sunmaid

Sunset

Sunny California __

Susan G. Tevis — 19

The Billionaire 30

The Eagle _ 26

The Grizzly _ 19

The Oriole _ 30

Tom ㄴ. 33

Tom Jones _ _ 30

Tommy Keith ____ 33

Tom Lundy 26

Tommy Atkins __... 19

Tom Thumb ___ 32

$\begin{array}{lr}\text { Trentonian } & 19 \\ \text { Tryphinnie } & 19\end{array}$

Uncle Sam _ 30

U. S. A. 19

Union Jack Cactus _ $\quad 26$

Union Jack Single_.. 32

Valentine 19

Vivandierre

W. E. Cooper $\quad 19$

White Dove $\quad 32$

Wizard of $\mathrm{Oz} \quad 19$

Wm. Welsh _ 32

Woozy of $\mathrm{Oz} \quad 19$

Yellow Gem ﹎.___... 33

Yuban $\quad 30$

Zante _._._. 26

Our 1927 Introductions.
Rollo Roy

Silver Medal ..._........ 3 


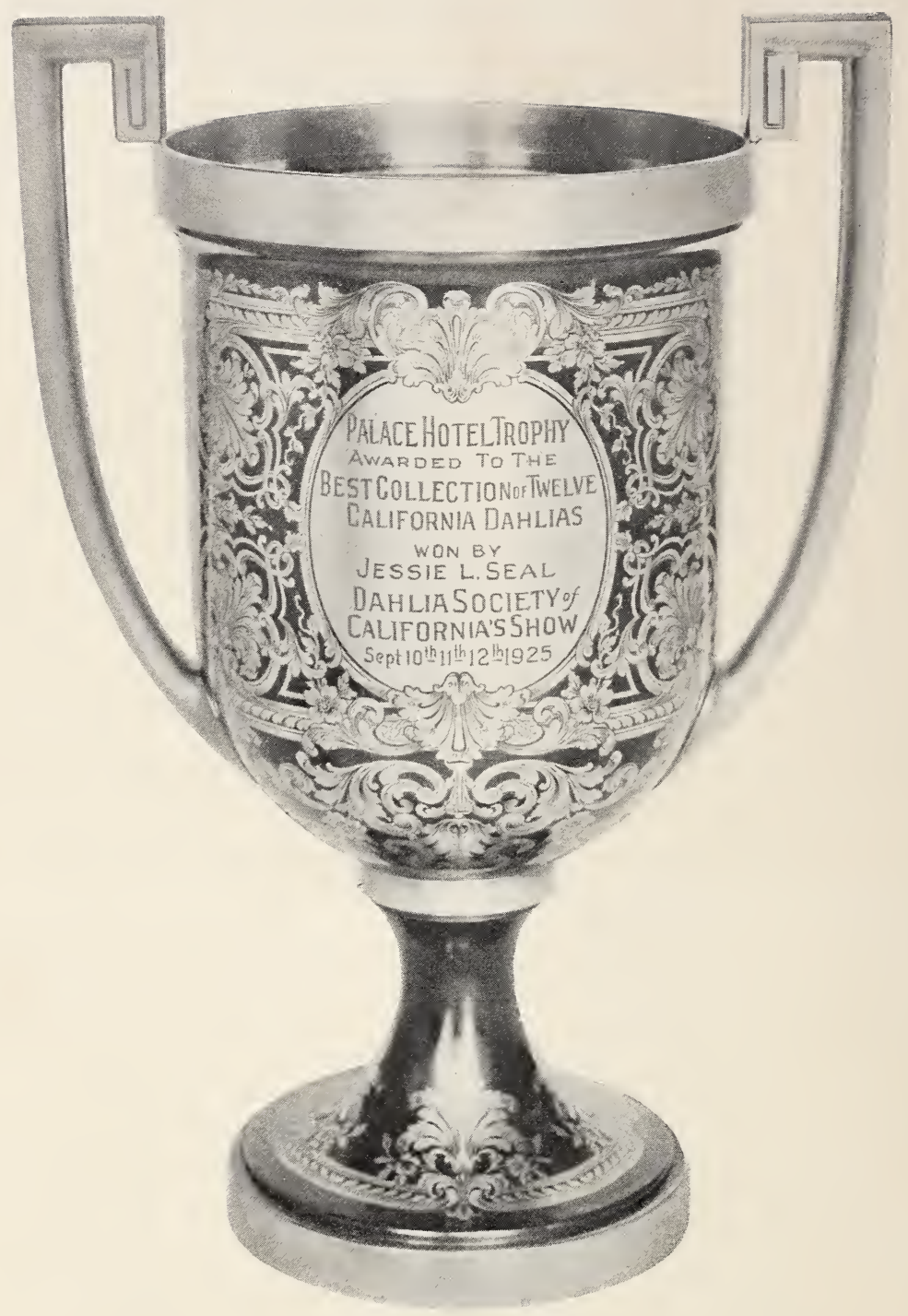

A cup, identical to the above, was awarded to us at the 1925 Palace Hotel Dahlia Show for the "Best Collection of California Dahlias", making the third consecutive year we have won this most coveted prize. 